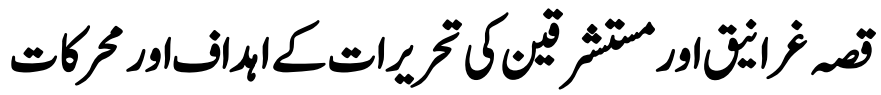

\section{The Targets and Motives of Orientalists Statements about Gharaneeq Story}

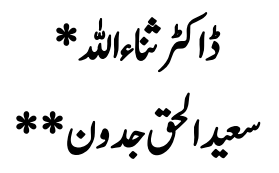

\begin{abstract}
The former orientalist conceived that the Holy Quran came as a result of efforts done by prophet, but there are orientalists who believe that it was not due to the efforts by human but it came over the passage of time. Generally, the orientalists made every effort to affront the true and holy image of last prophet PBUH-the final messenger of Allah as well as the Quran, (revealed words of Allah) in a bid to create ambiguity and hurt the reliability of both. They also left no opportunity to touch and allegedly refer to as Satanic verses. Some of them who are more significant in paying heed specifically to this issue in their work are Karen Armstrong, Montgomery Watt and Maxims Robinson. According to objective of their work is to prove this fallacy that Quran does not come due to revelation from Allah. But, most famous Muslim scholars like Al-Qurtabi, Al-Radi, Qadi Ayaz and Ibn alArabi provided proofs that this is only myth and Satanic verses have no base at all. The article is focused to analyse the Orientalists views on the satanic verses and their drastic failure in upholding their objectivity pertaining to the false story. This research paper is intended to study that how they failed in proving the major objectives of the false story.
\end{abstract}

Key Words: Quran, Satanic Verses, Orientalists, Muslim Scholars.

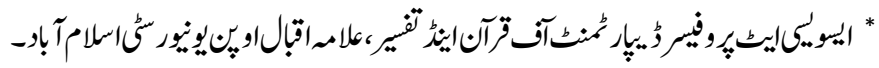

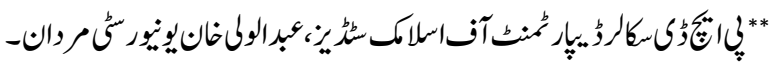


جزرك-جون2019

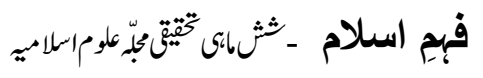

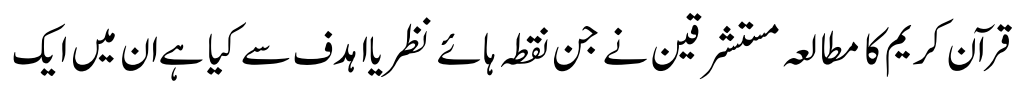

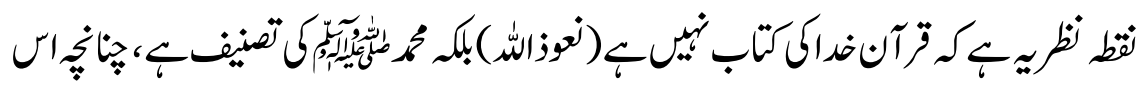

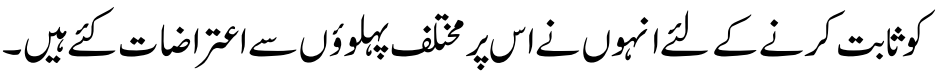

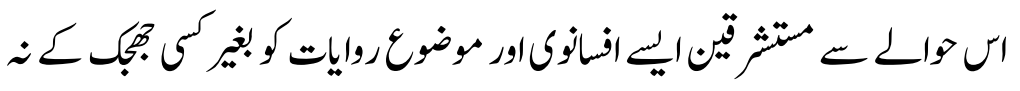

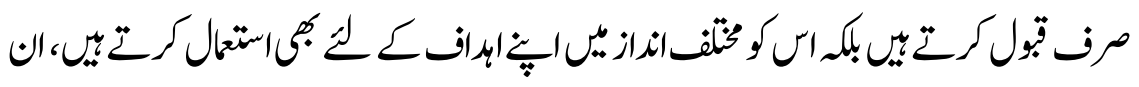

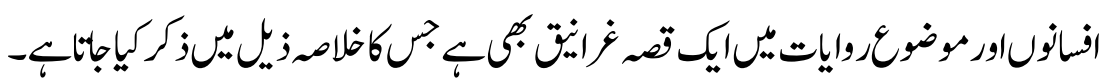

قصم غانتقكيك منظم

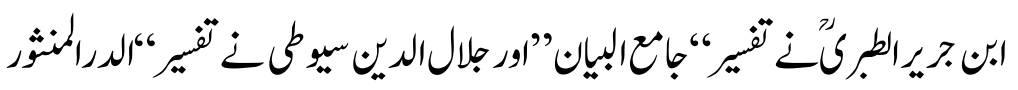

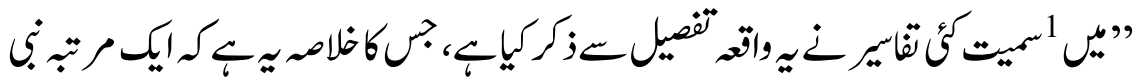

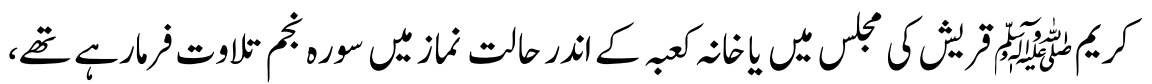

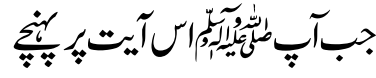

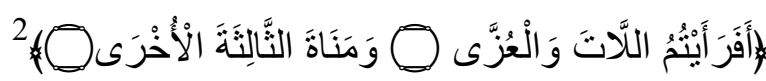

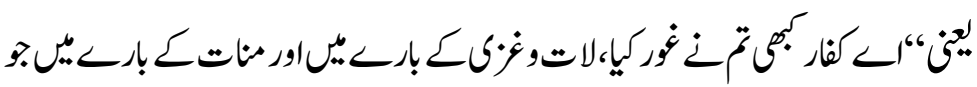

"تيرك"

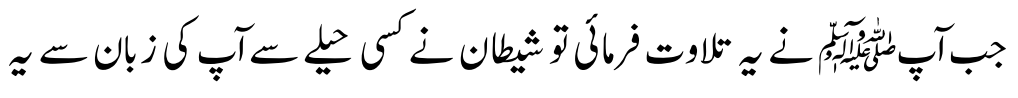

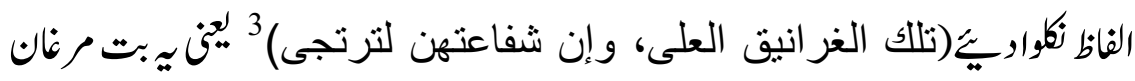

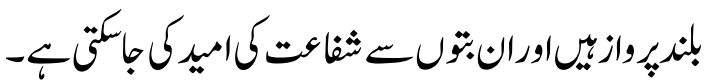

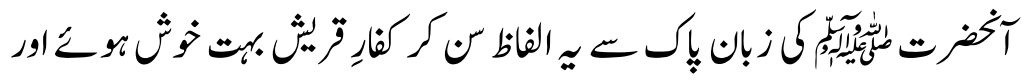

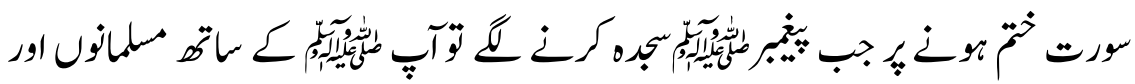

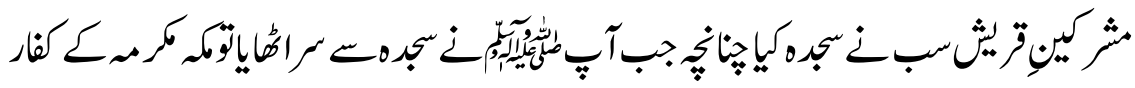

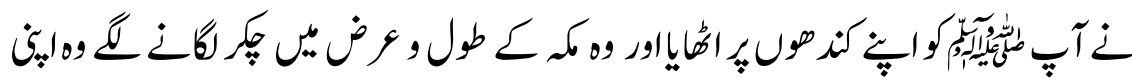

38 


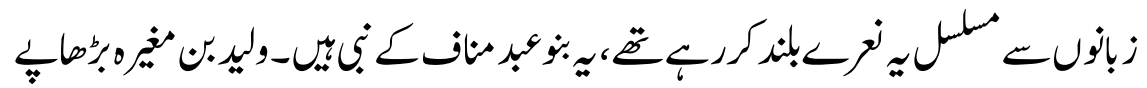

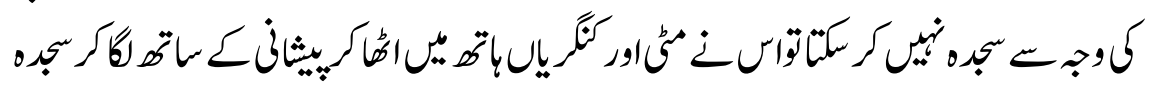

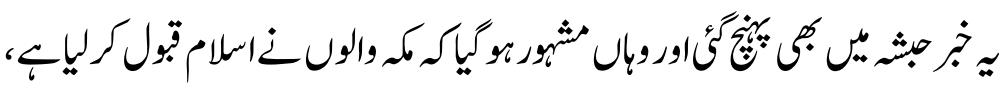

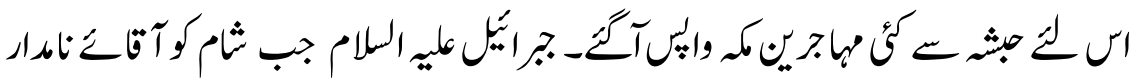

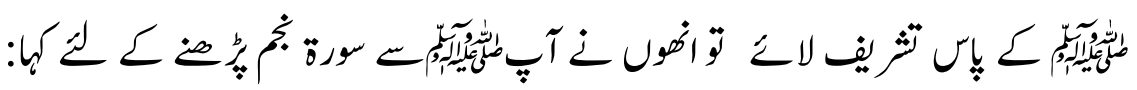

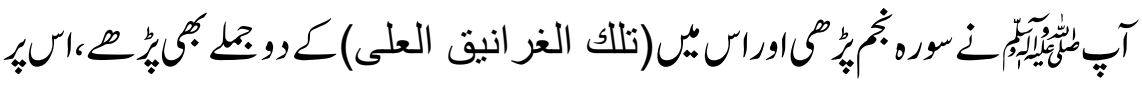

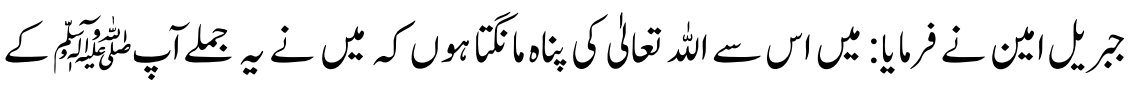

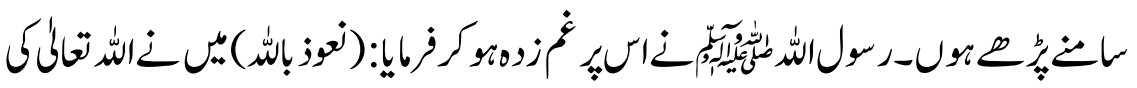

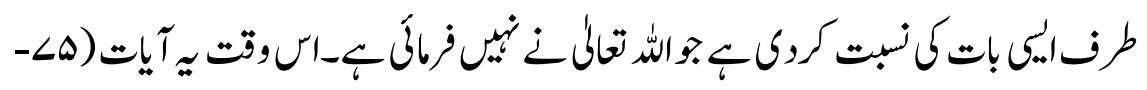

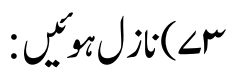

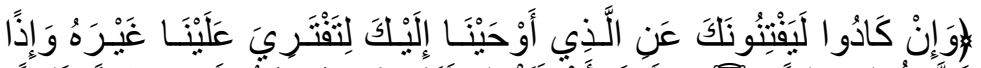

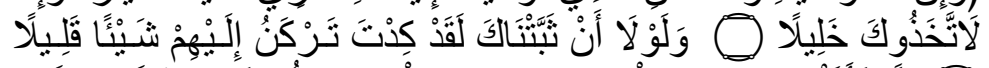

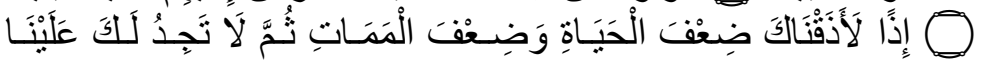

$$
\text { نَصِيرًا }
$$

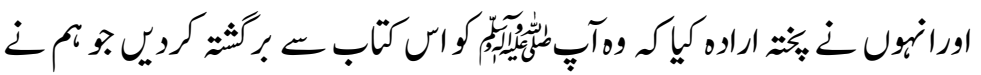

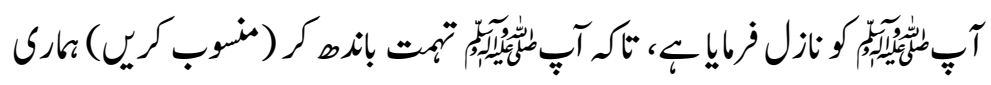

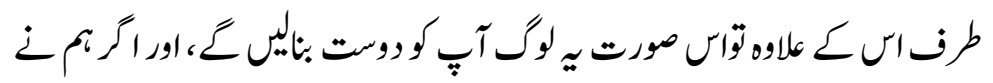

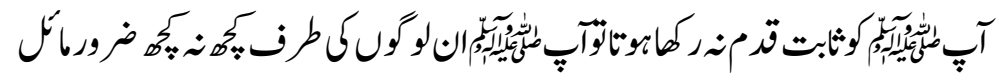

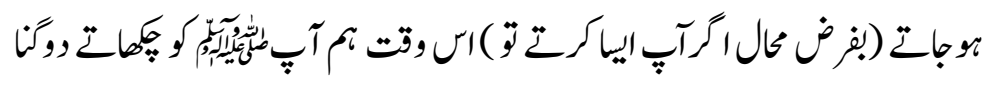

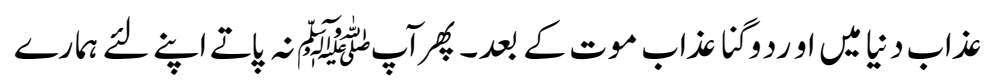

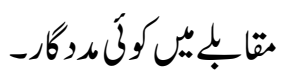




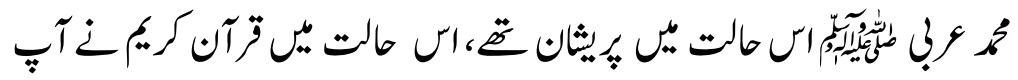

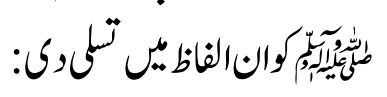

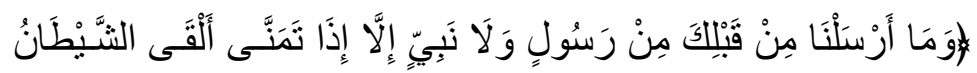

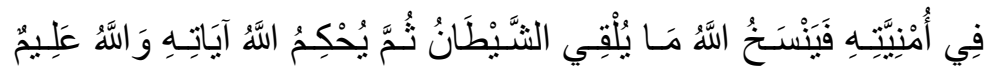

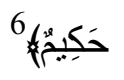

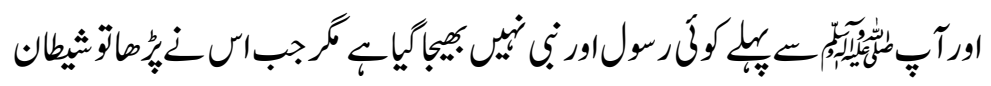

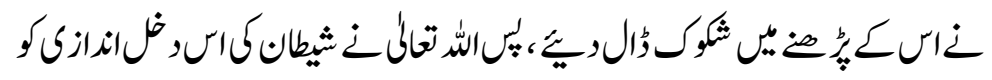

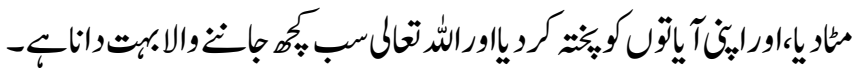

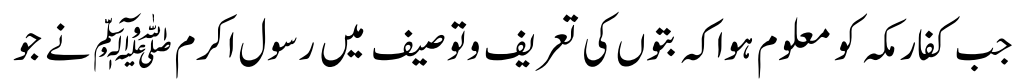

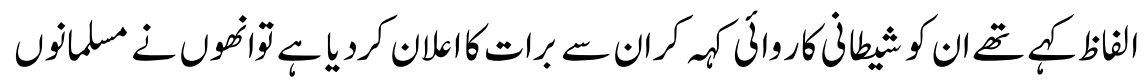

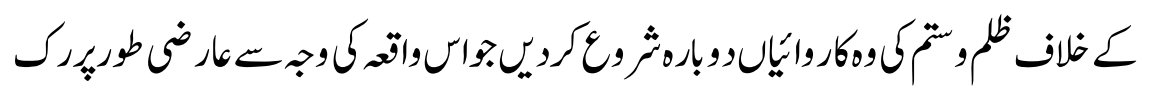

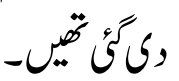

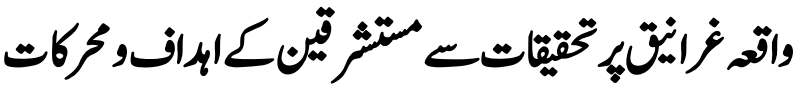

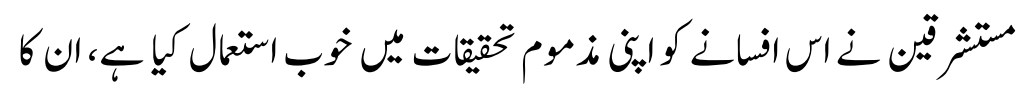

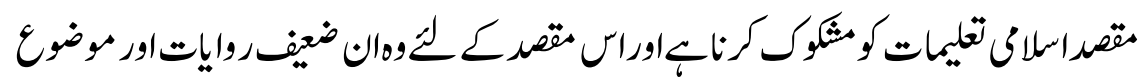

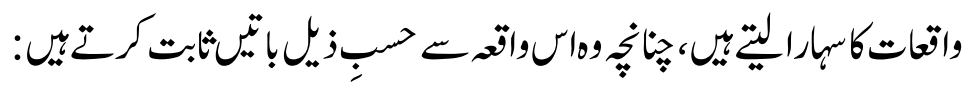

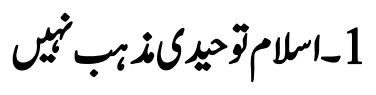

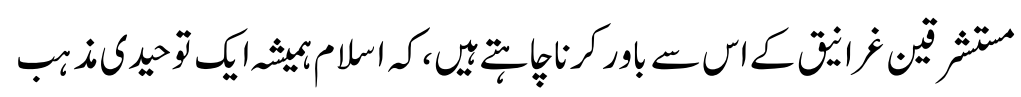

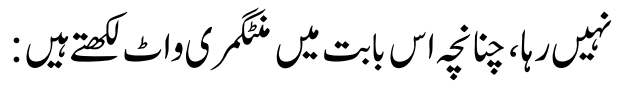




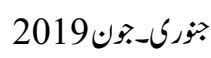

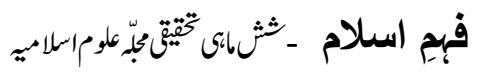

“

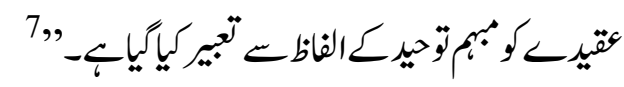

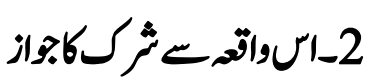

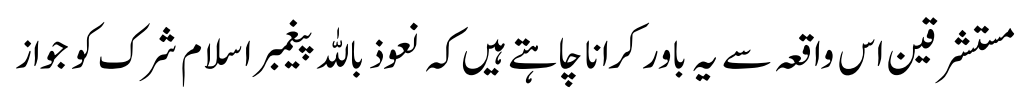

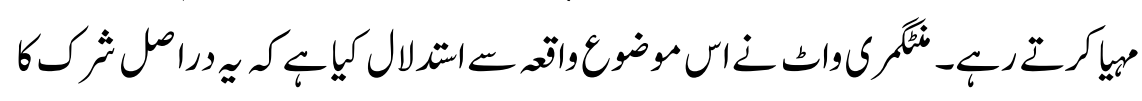

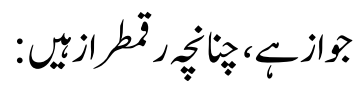

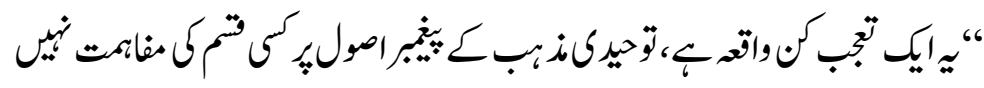

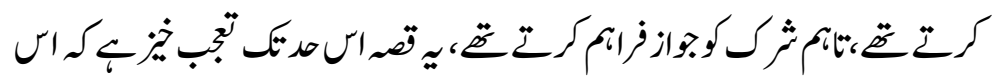

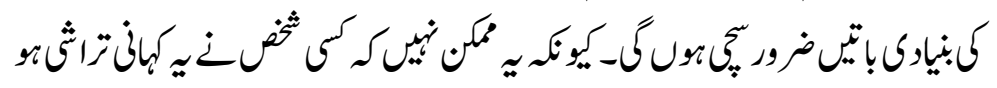

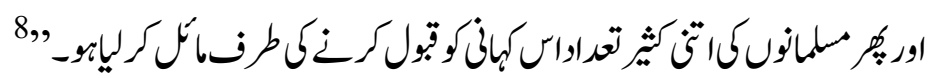

3:ناخُونموخكالاكوروائره

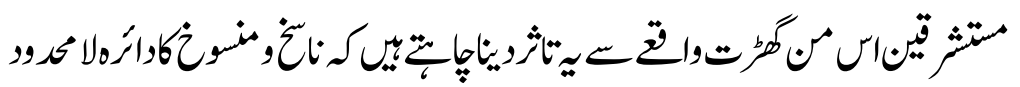

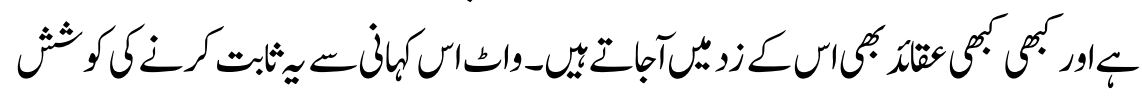

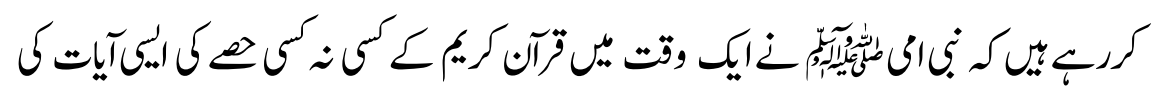

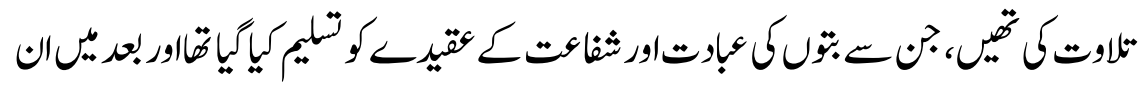

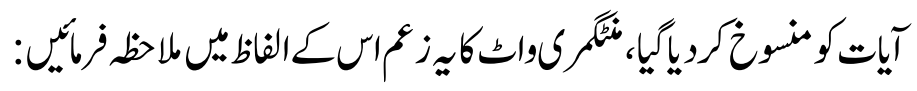

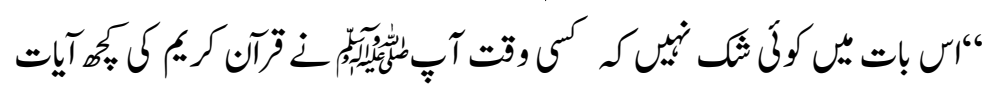

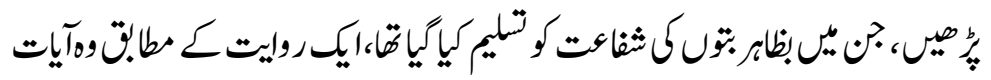

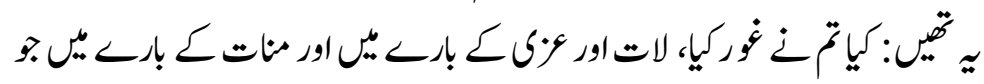

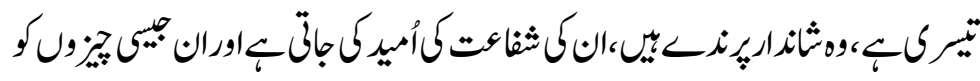

41 


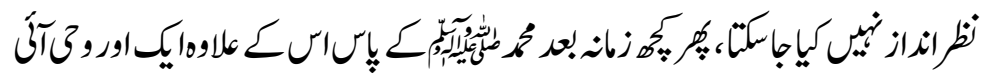

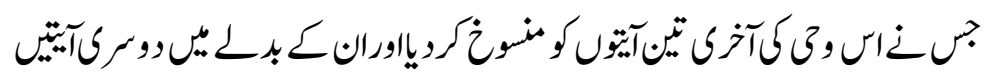

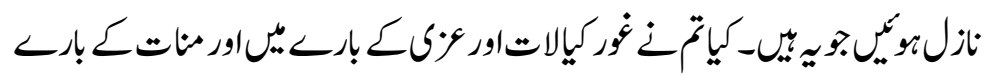

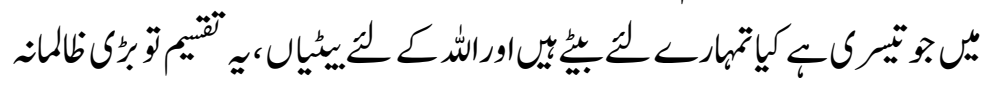

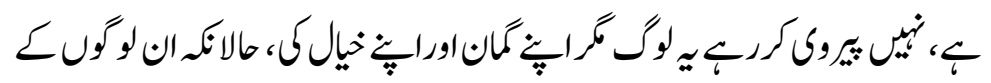

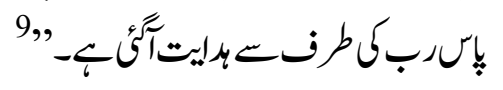

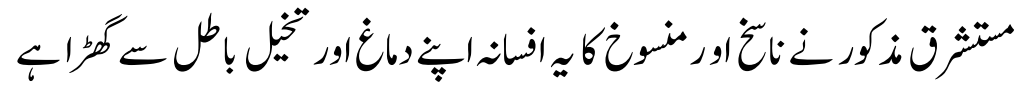

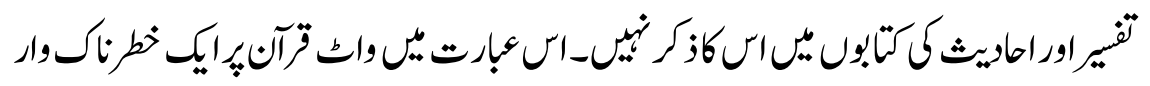

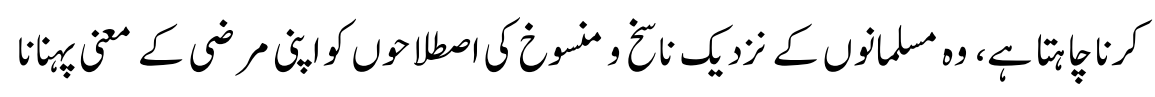

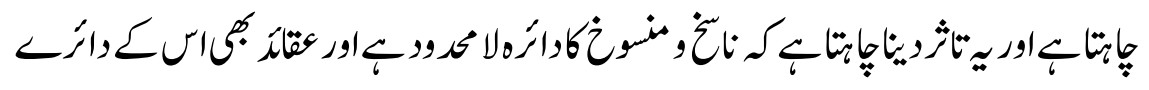

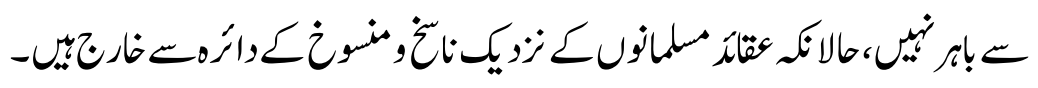

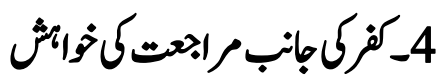

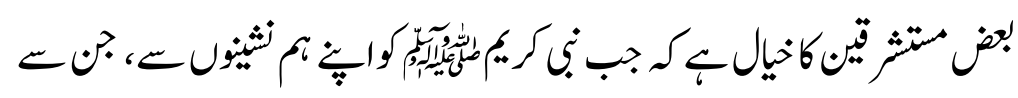

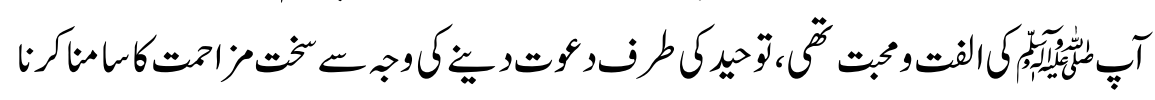

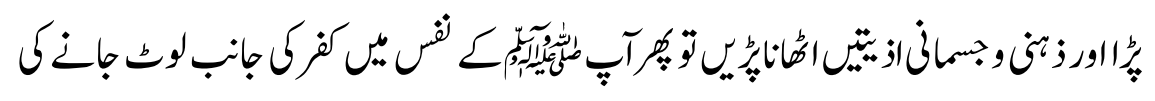

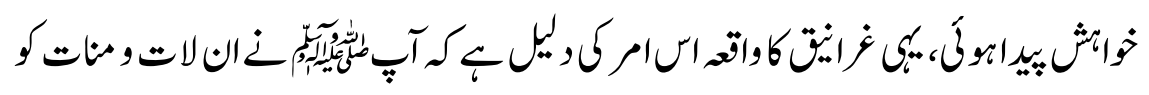

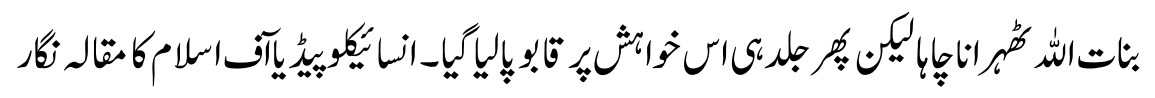
الكثناب

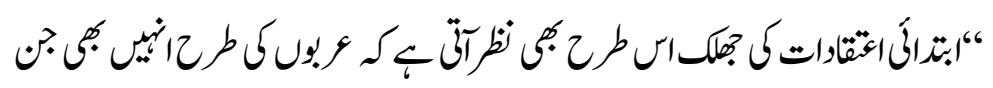

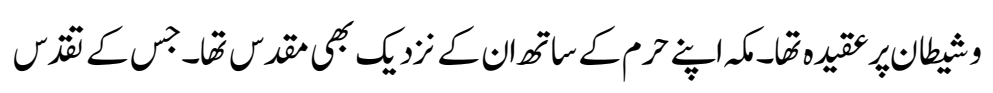




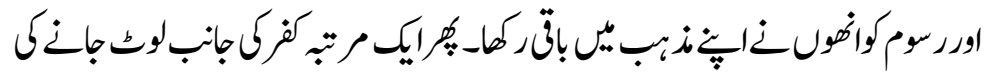

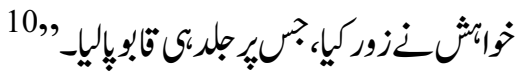

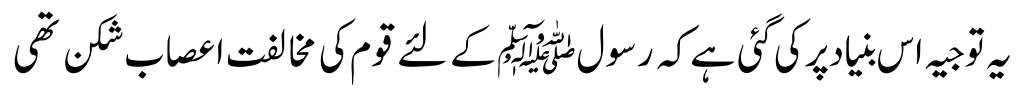

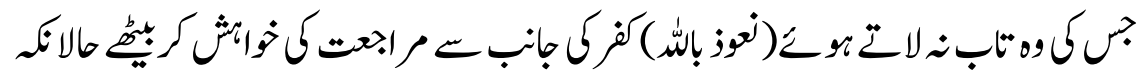

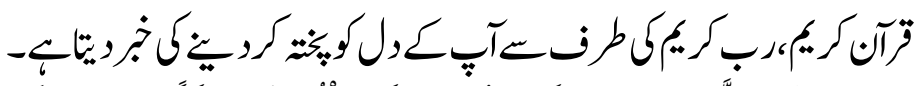

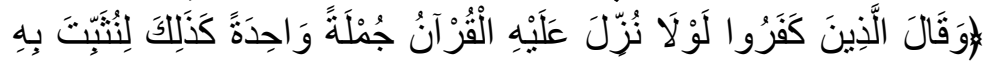

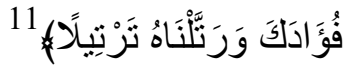

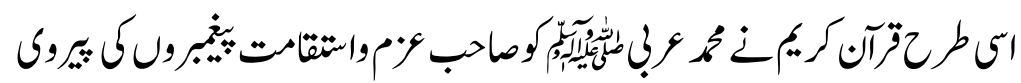

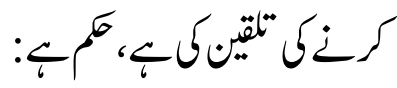

$$
\begin{aligned}
& 12
\end{aligned}
$$

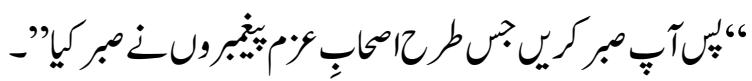

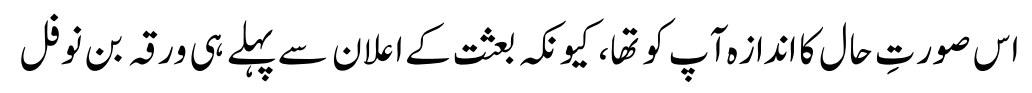

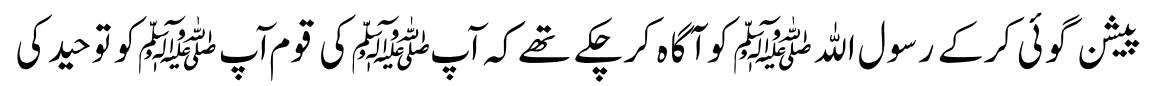

$$
\text { 13. }
$$

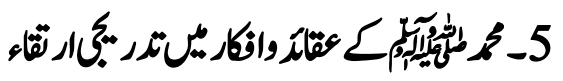

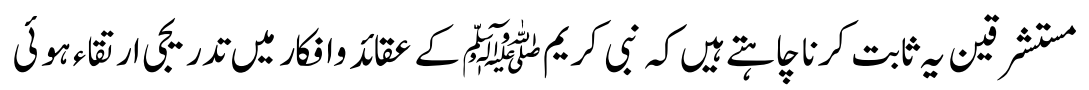

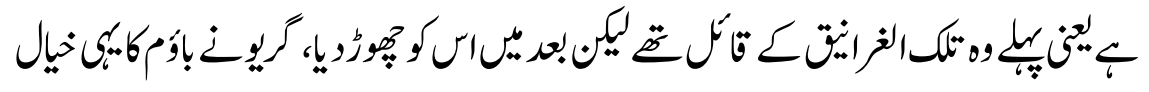

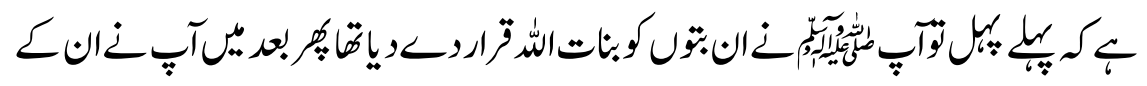

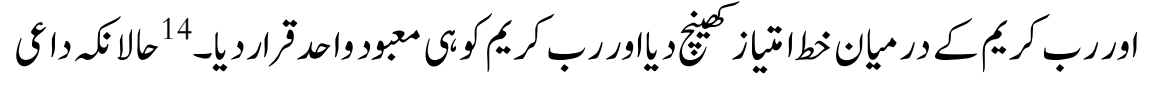


جزرك-جون2019

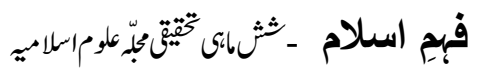

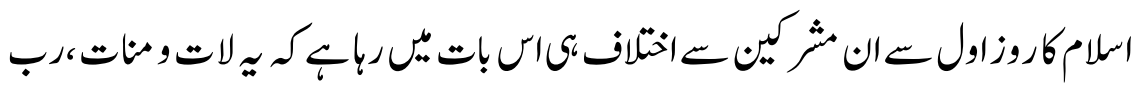

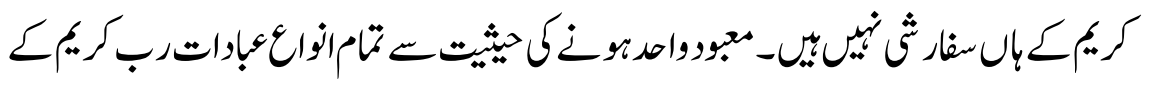

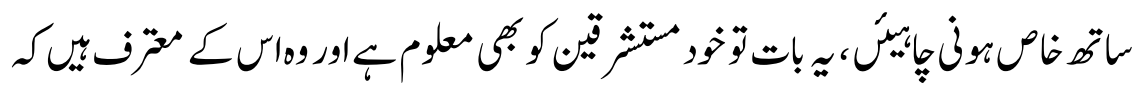

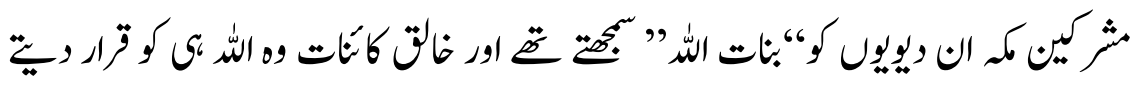

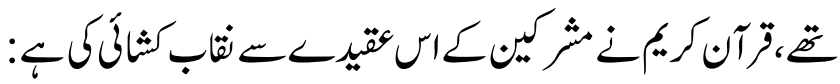
15

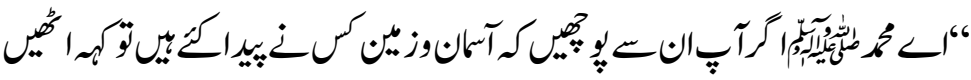

ع اللّن

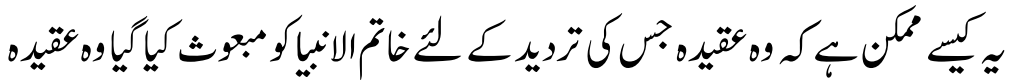

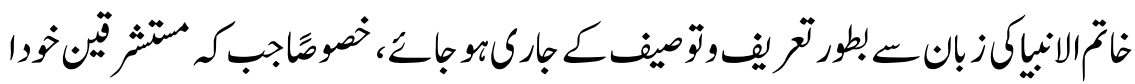

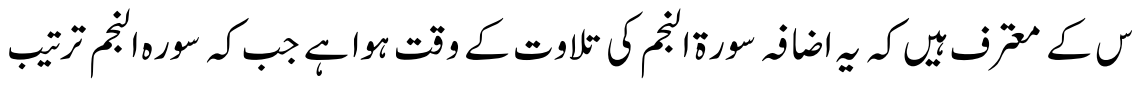

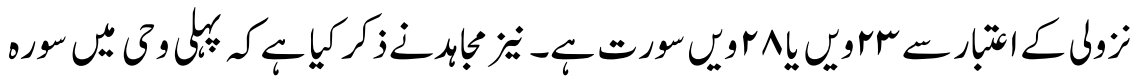

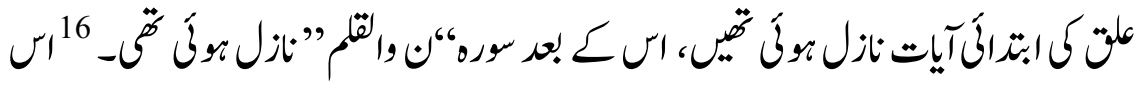

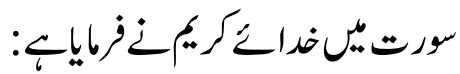

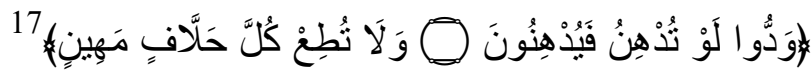

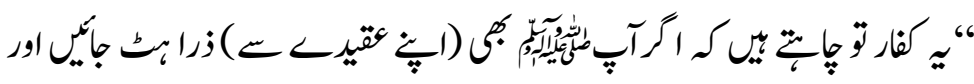

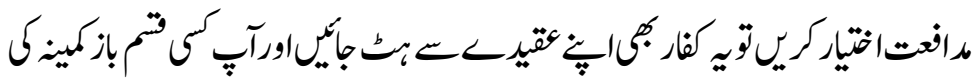

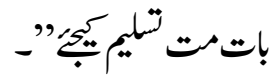

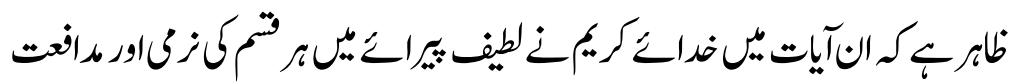

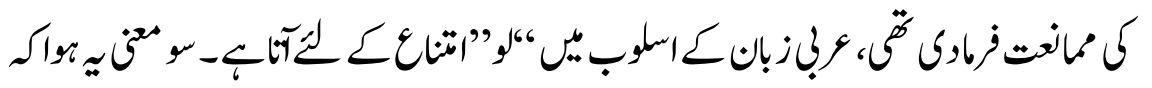

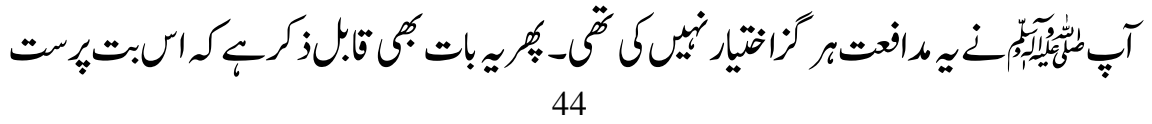




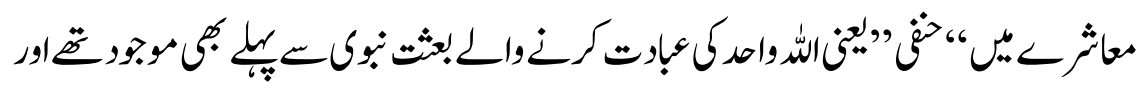

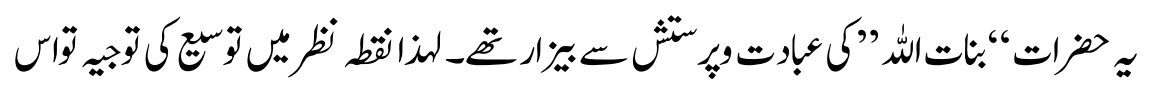

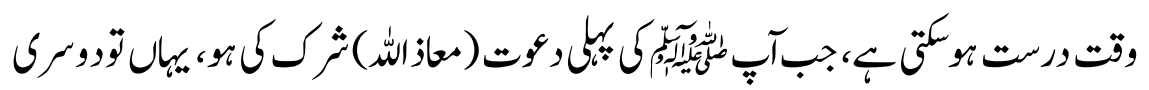

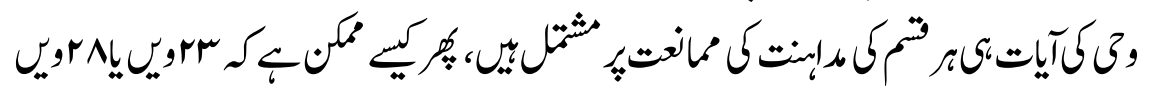

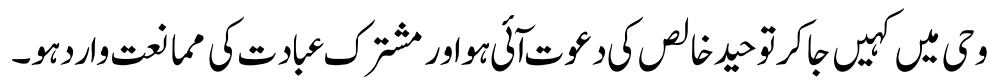

\section{6ـوقتّجذب منامت}

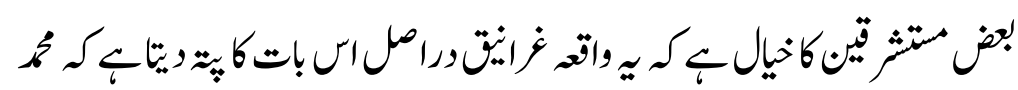

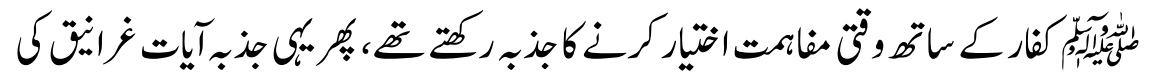

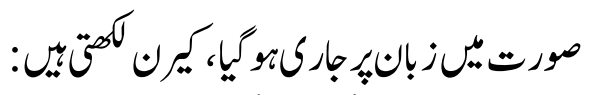

The Quran also refers to a moment when, it seems, Muhammad had tried to reach out to the Quraysh to still their fears and in the hope ofre-establishing friendly relations. ${ }^{18}$

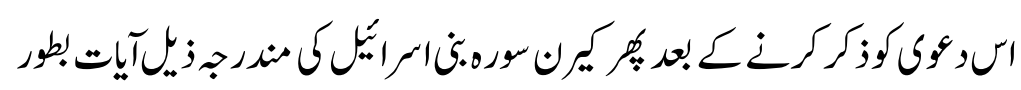

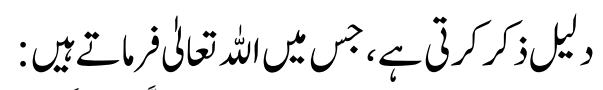

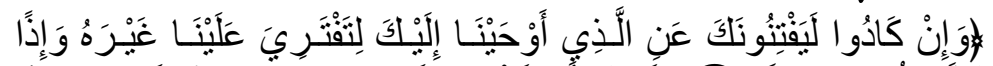

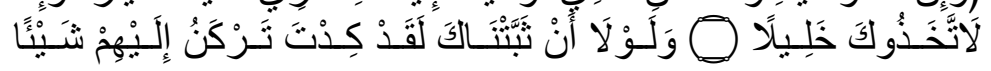

19

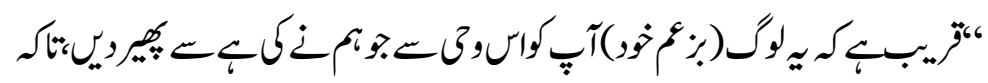

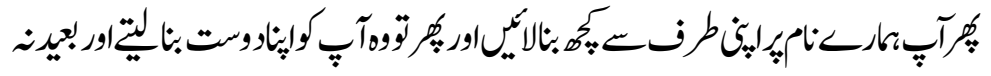

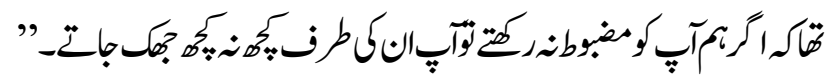

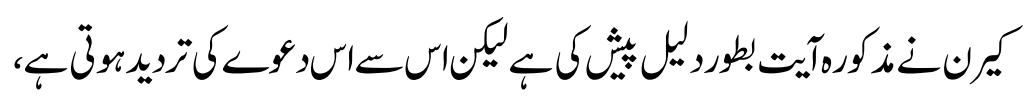

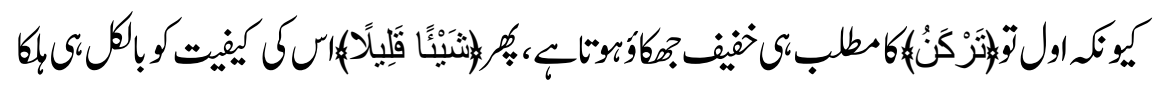




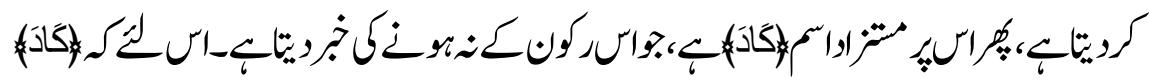

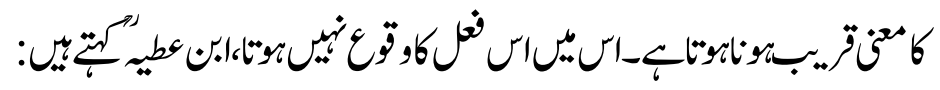

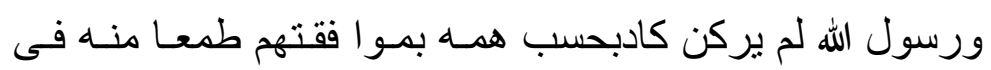

$$
\text { استئلافهم } 20
$$

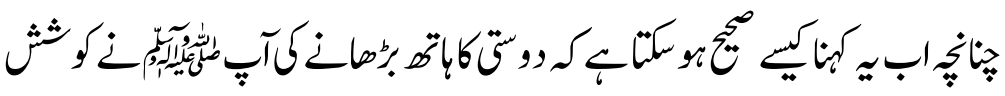

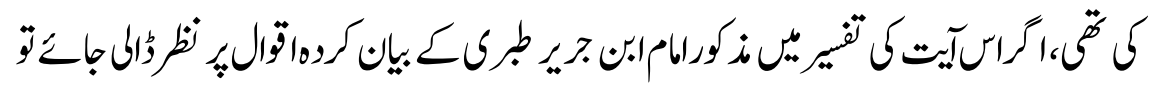

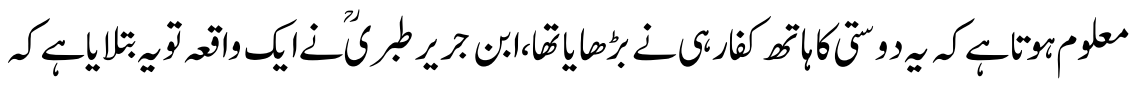

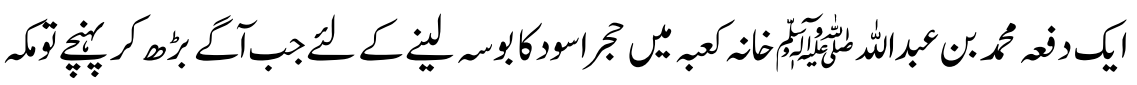

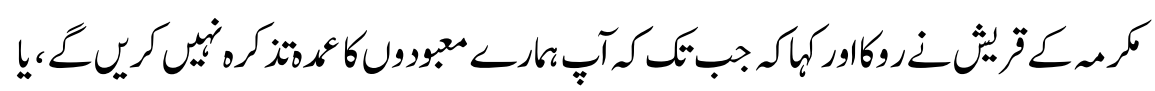

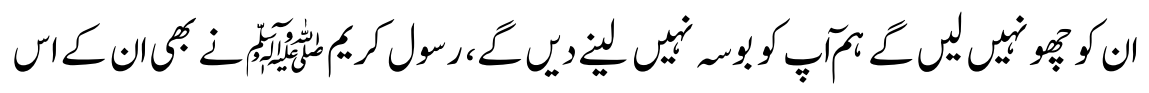

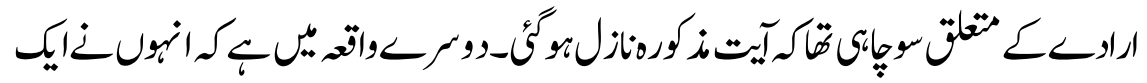

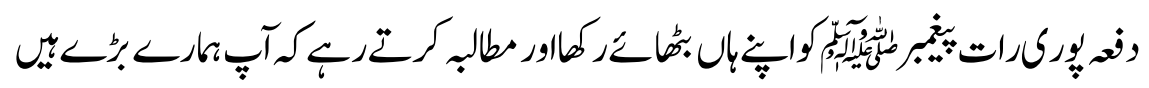

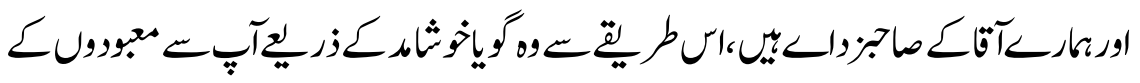

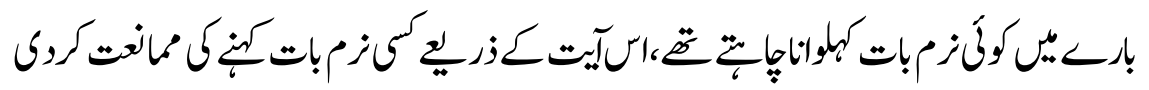

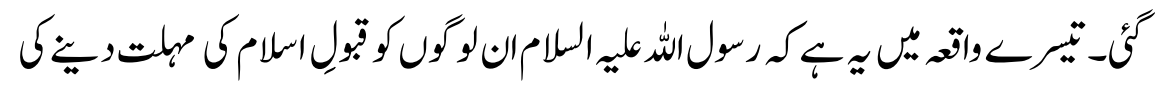

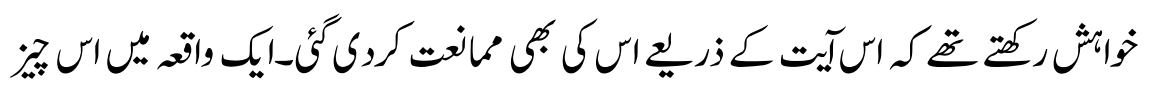

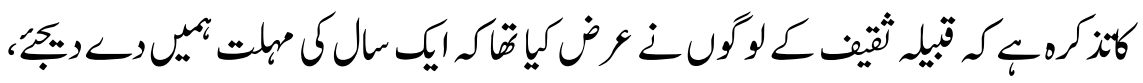

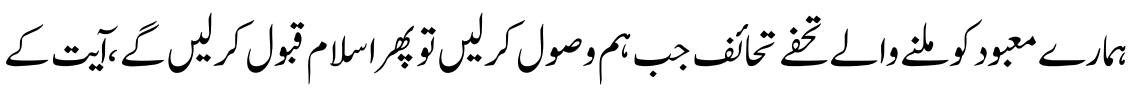

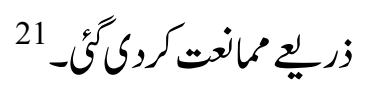

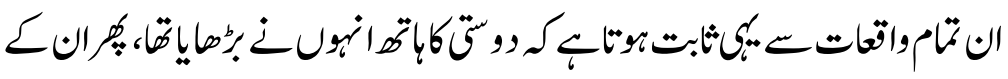

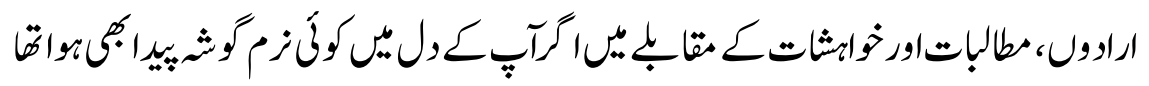




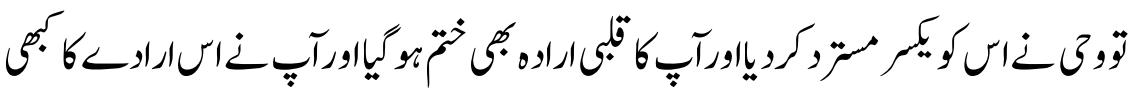

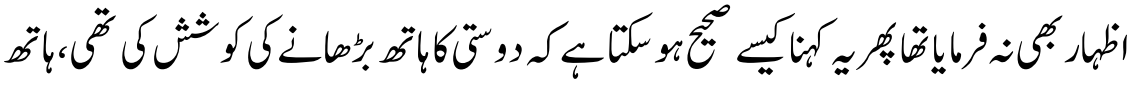

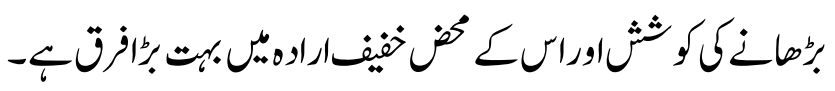

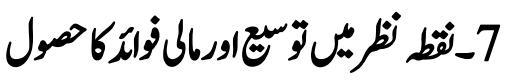

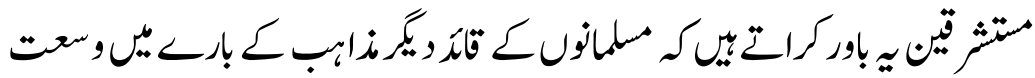

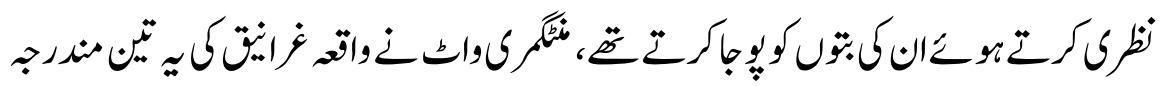
بالاتجيهات كبيلوه كمتاك:

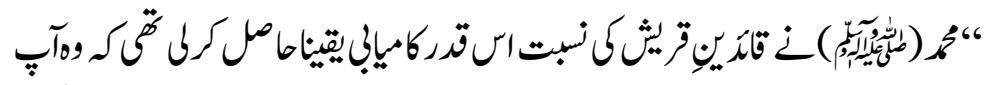

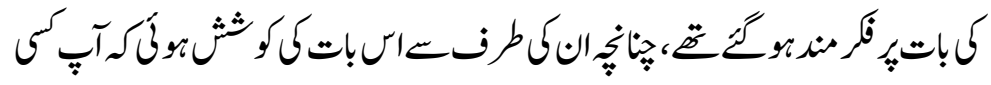

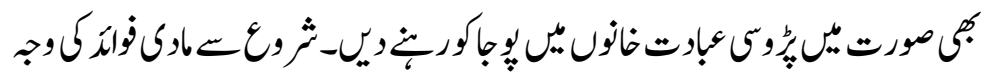

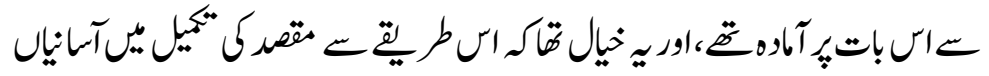

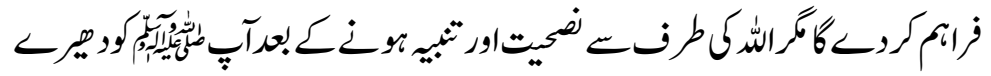

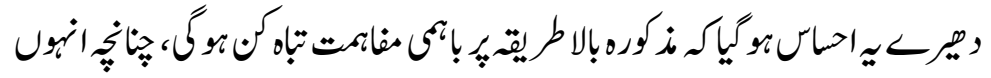

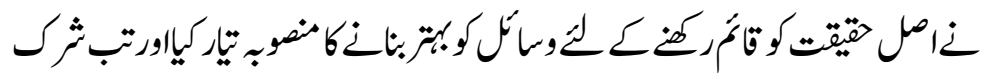

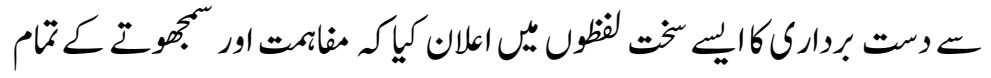

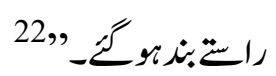

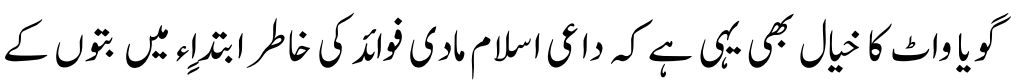

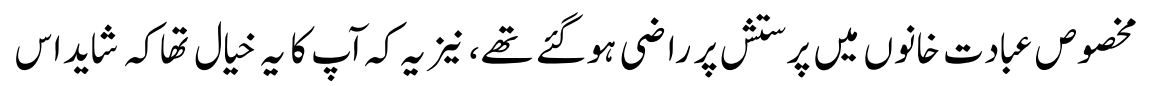

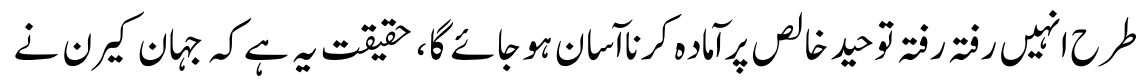

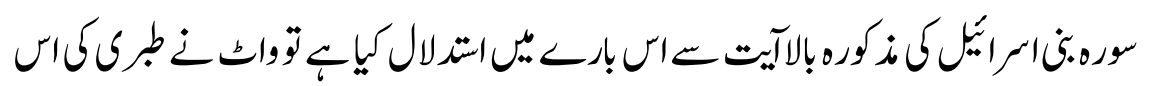

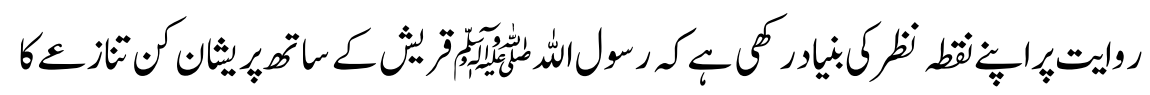


صل تالثكرن

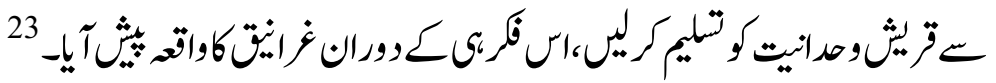

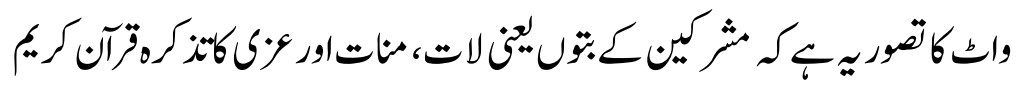

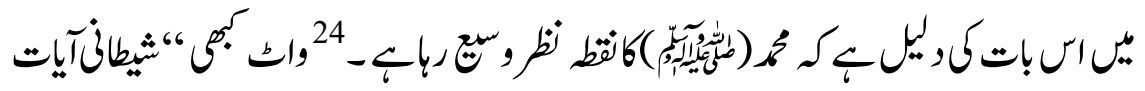

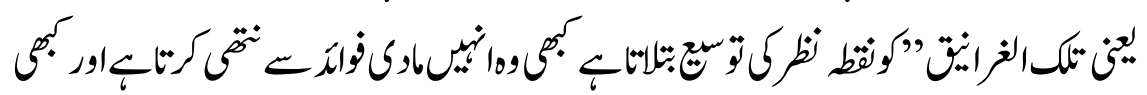

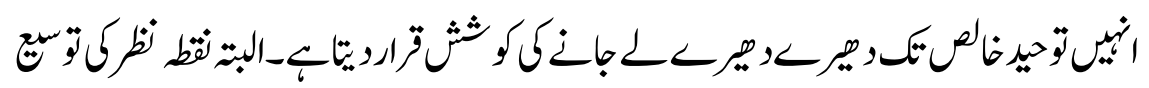

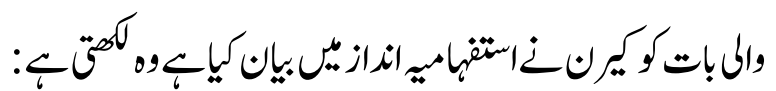

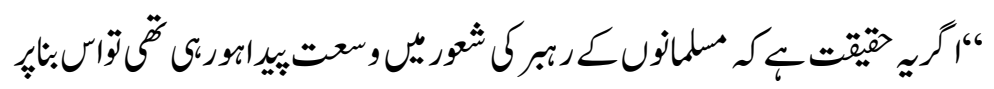

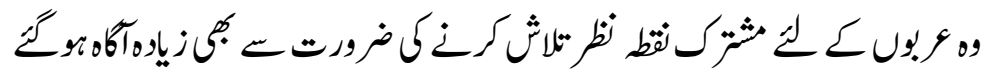

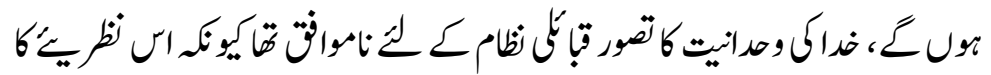

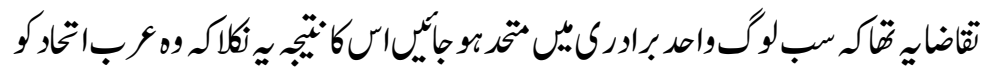

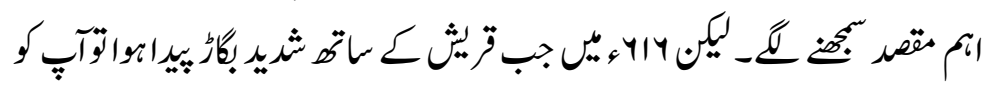

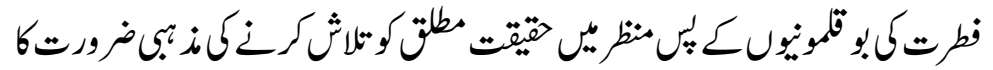

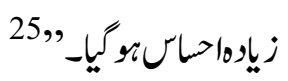

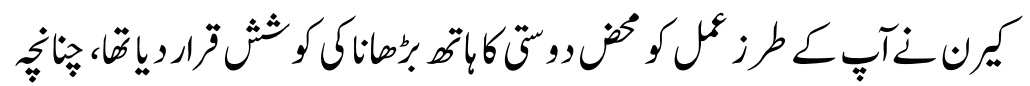

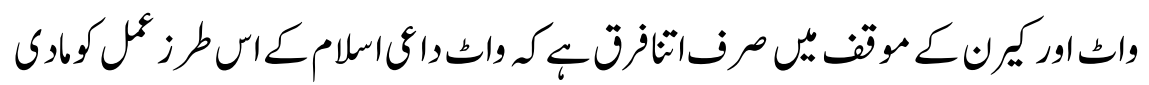

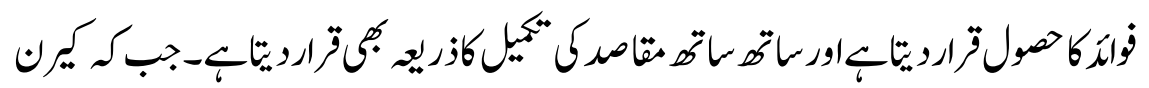

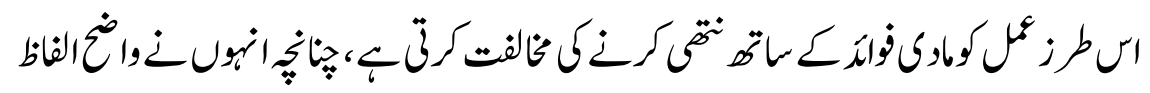

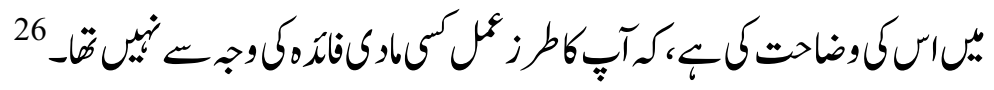

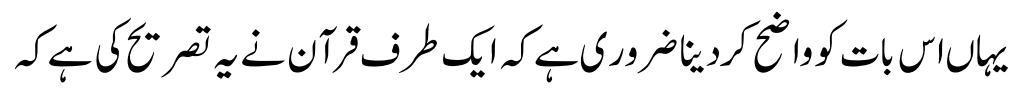

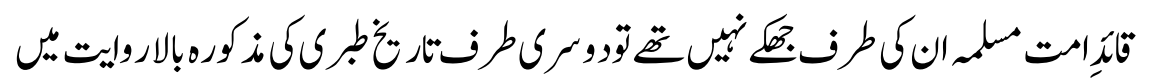




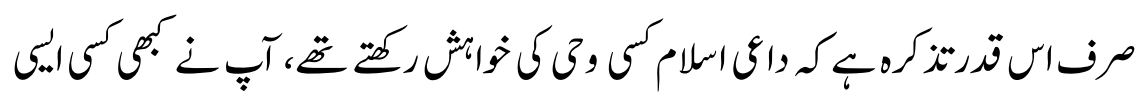

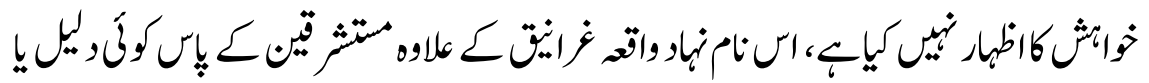

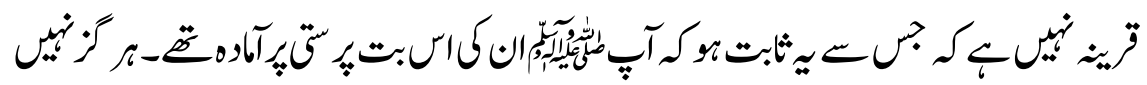

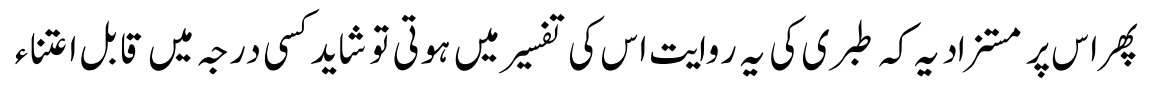

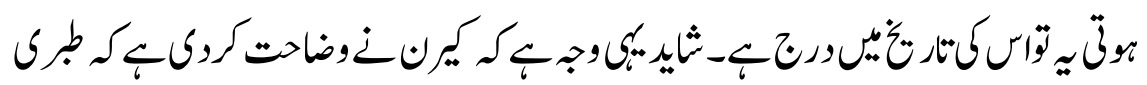

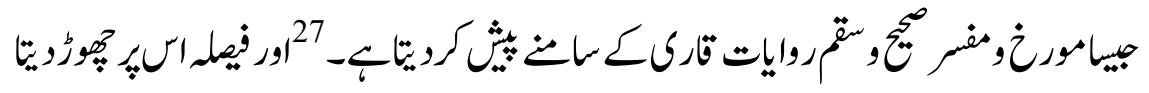

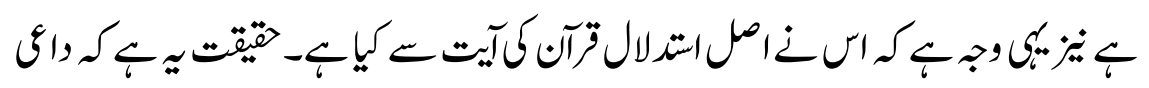

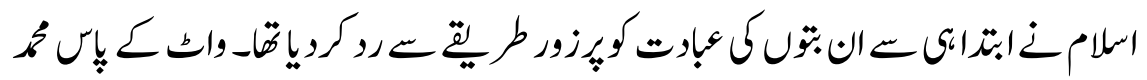

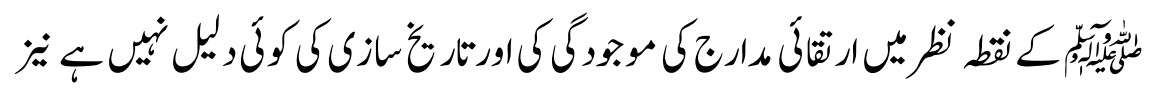

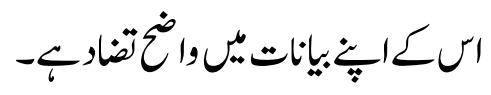

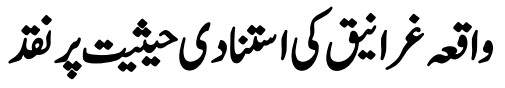

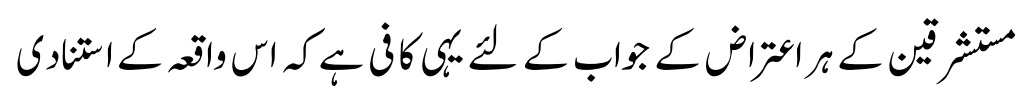

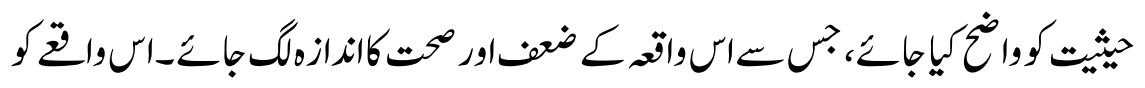

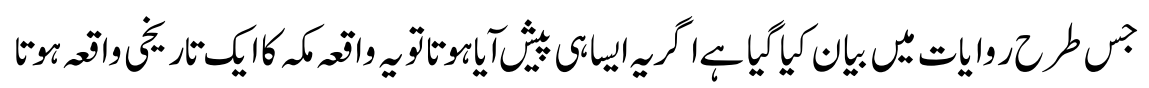

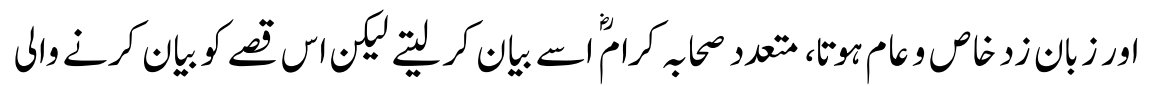

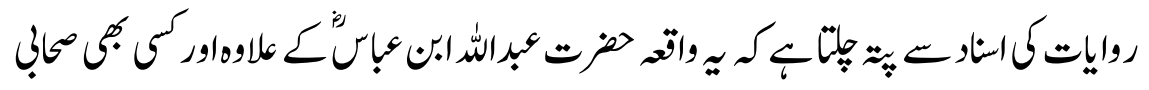

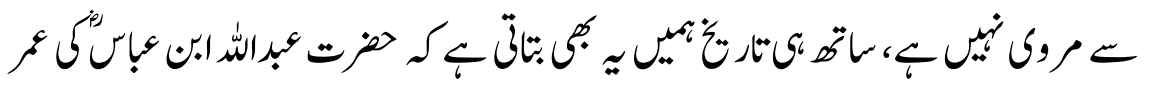

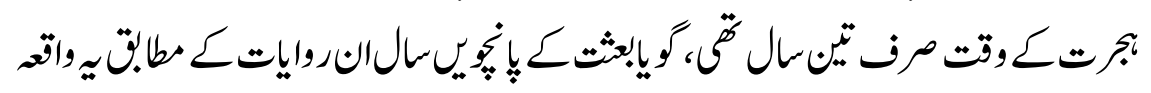

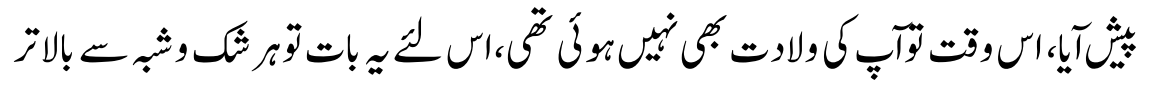

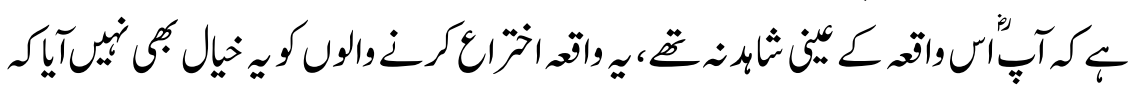




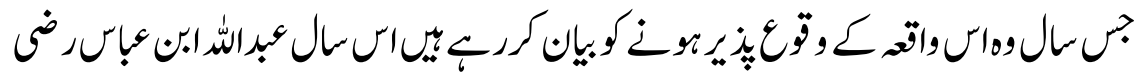

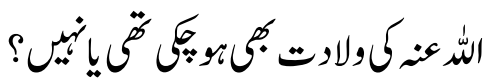

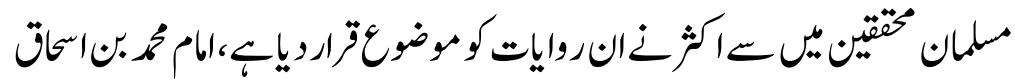

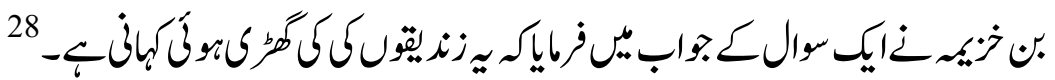

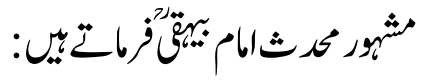
هذه القصة غير ثابتة من جهة النقل 29

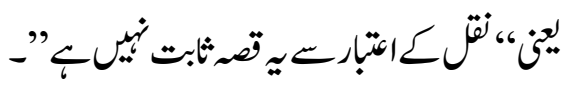

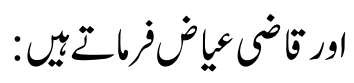

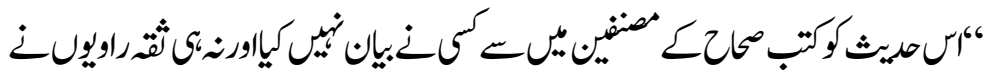

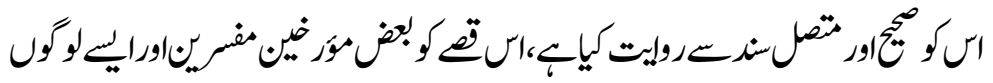

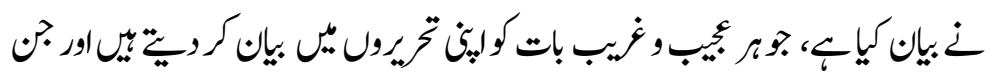

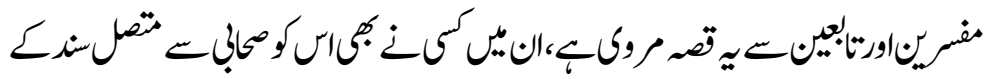

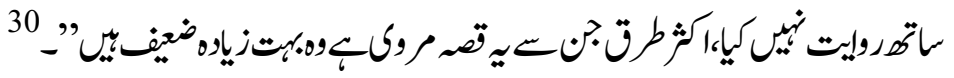

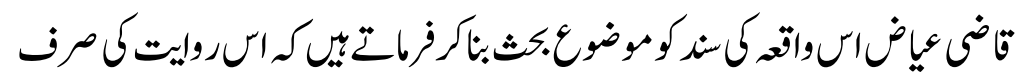

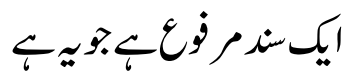
“شعبة عن ابى البشر عن سعيد بن جبير عن ابن عباس

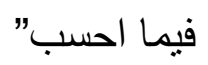

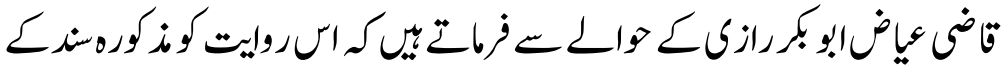

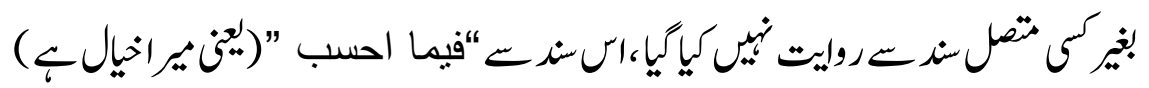

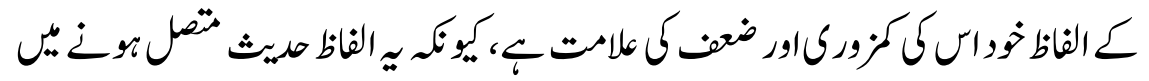

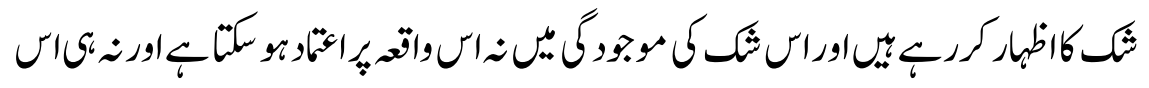
ككوكَّثيتت 


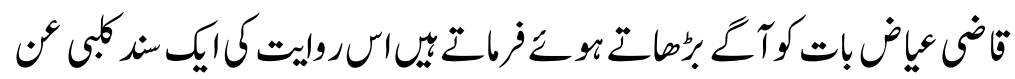

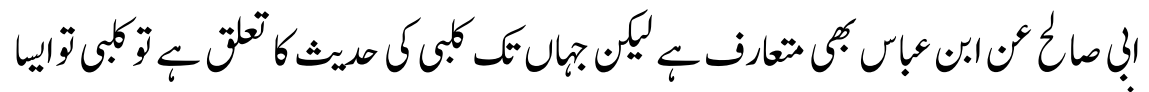

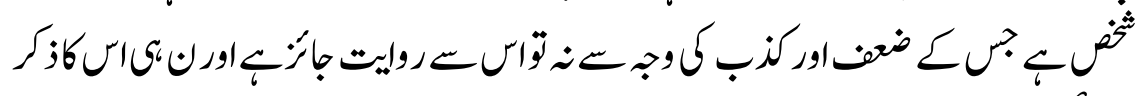
كرنا تصيح-ب 31

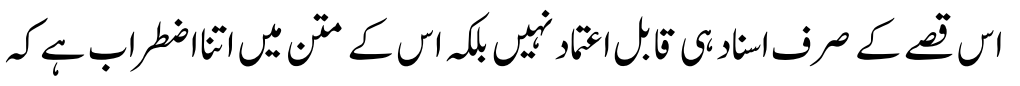

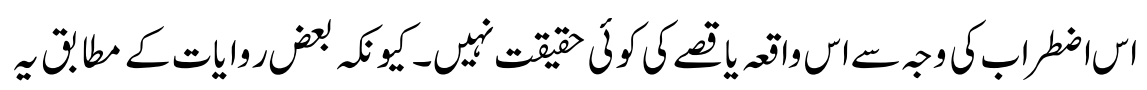

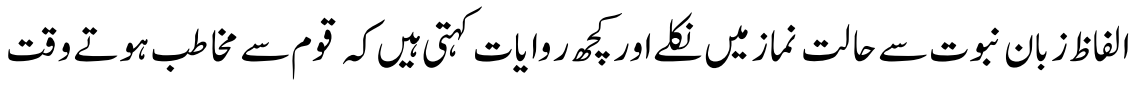

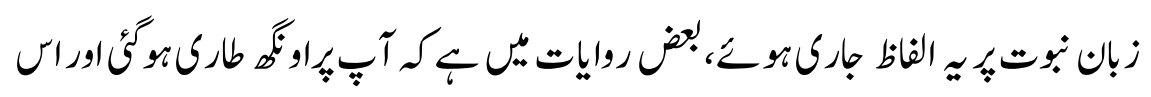

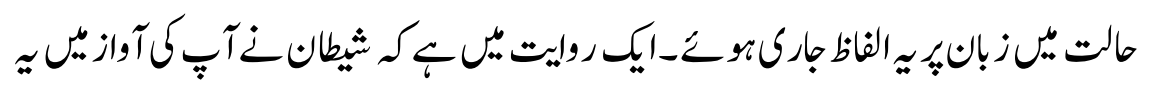

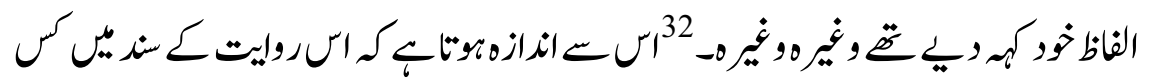

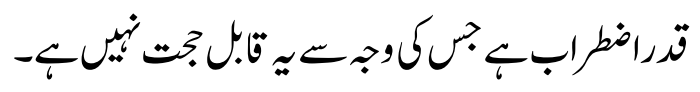

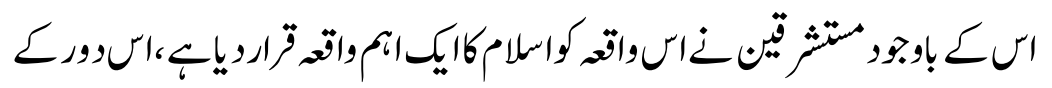

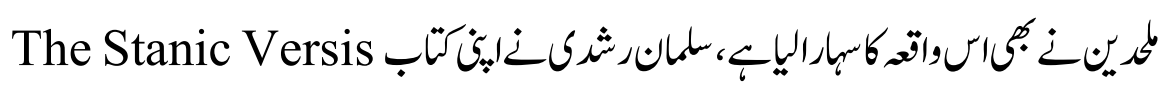

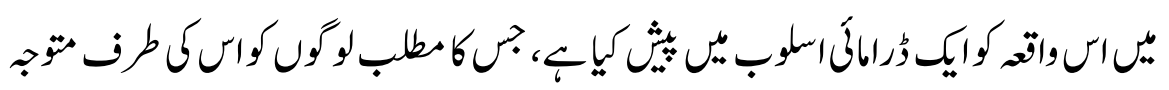

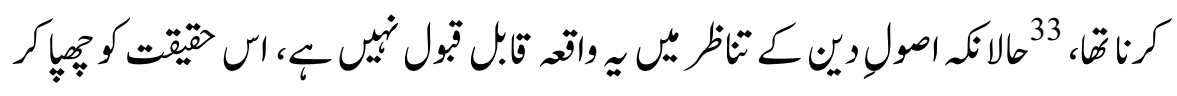

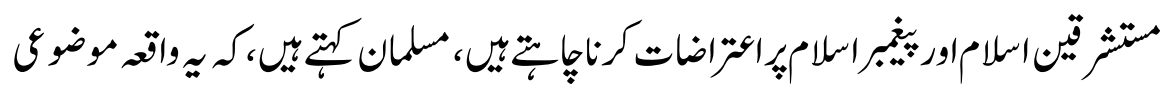

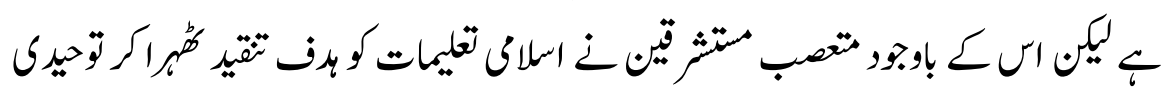

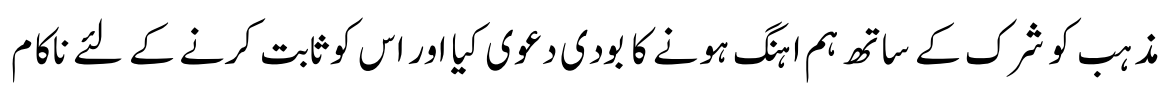

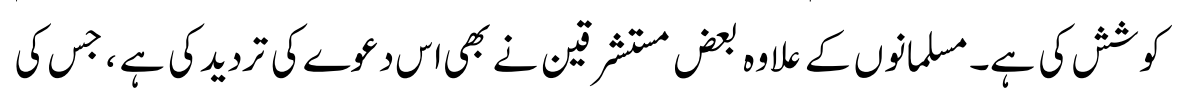

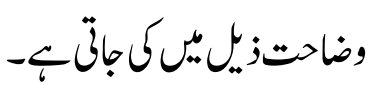




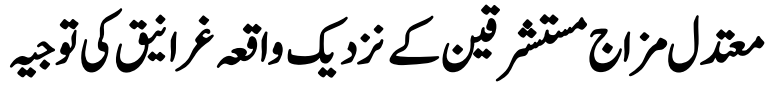

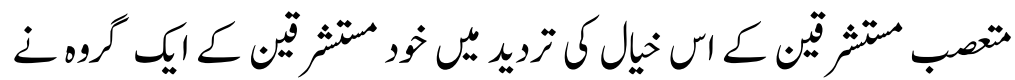

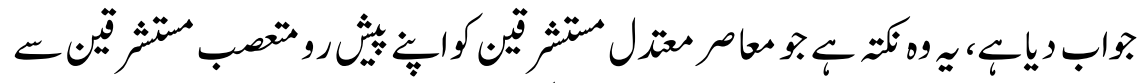

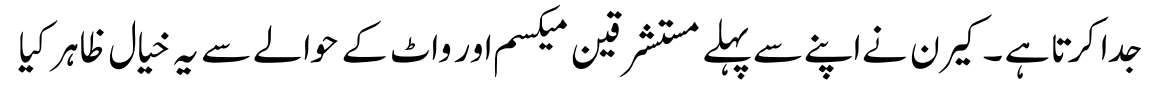

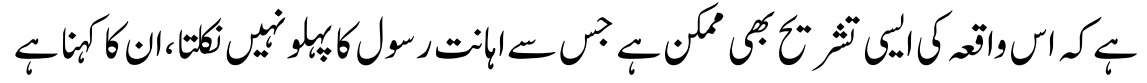

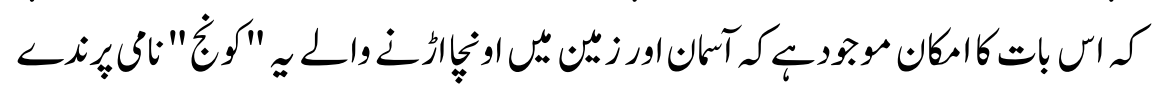

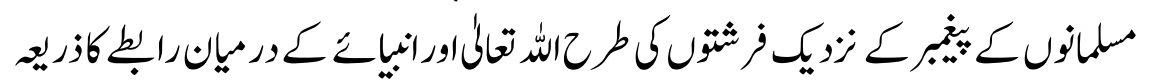

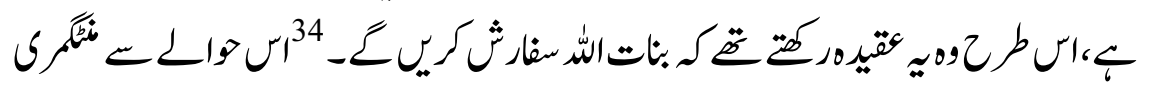
واشت ذلكابح:

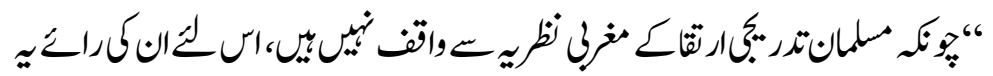

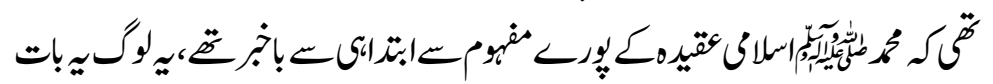

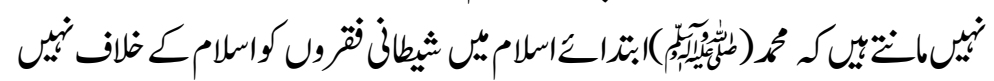

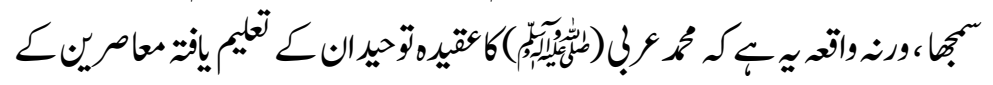

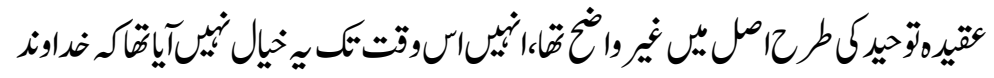

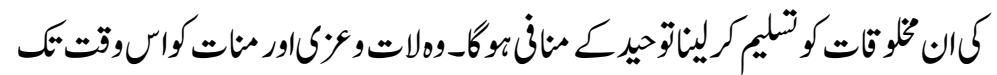

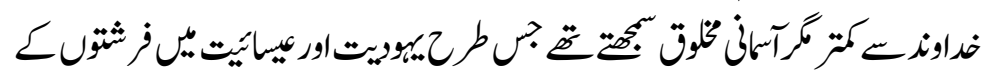

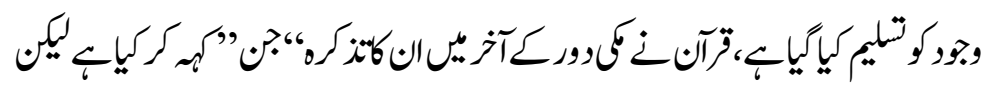

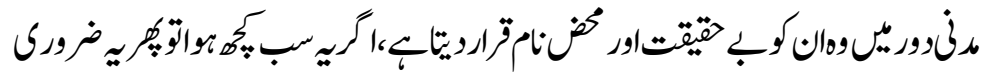

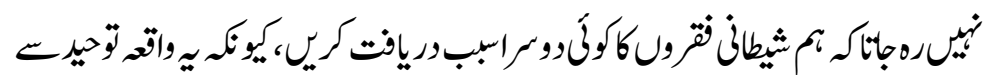

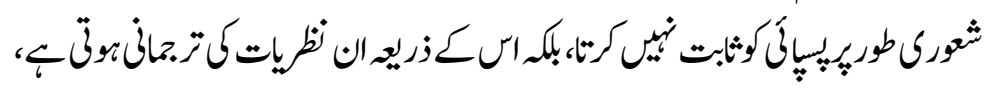

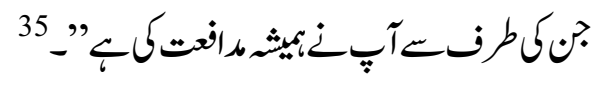




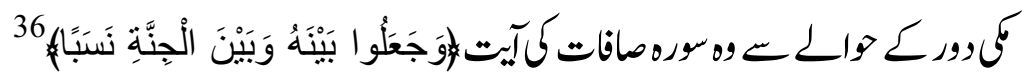

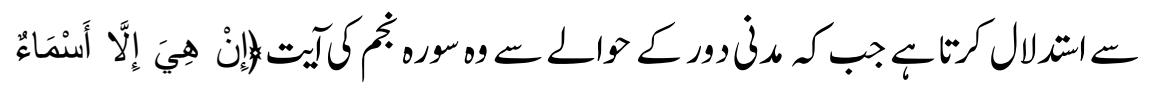

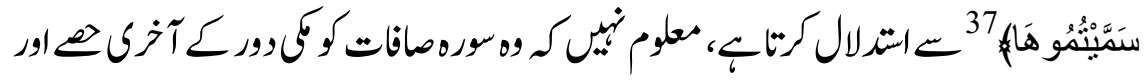

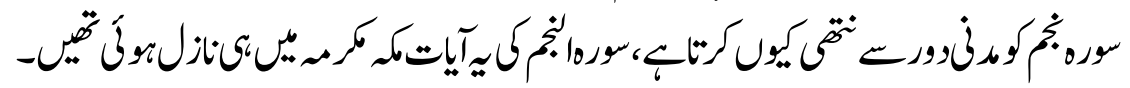

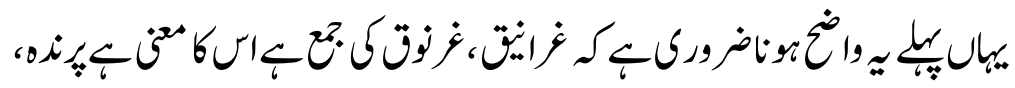

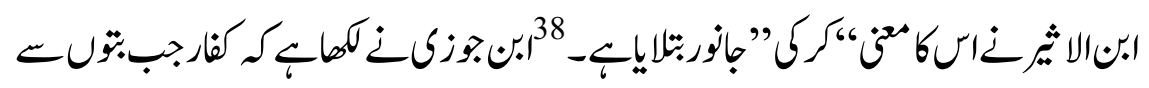

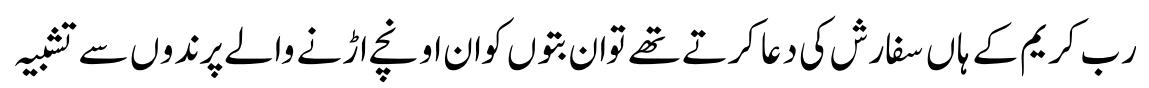
39 ,

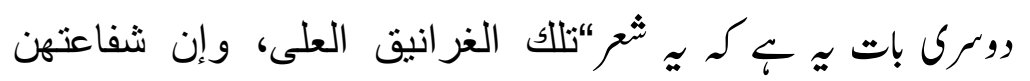

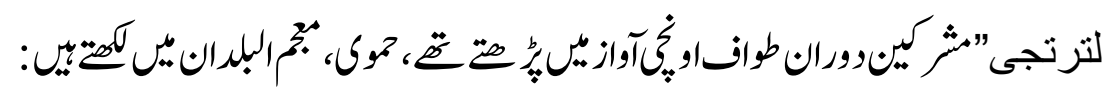

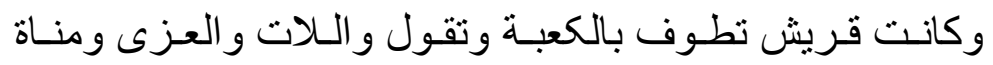

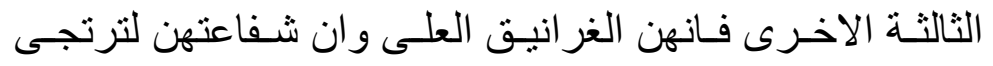
وكانو يقولون بنات الله عزوجل وهن يشفعن اليه

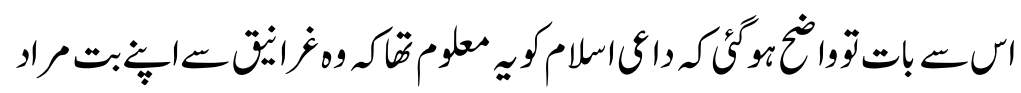

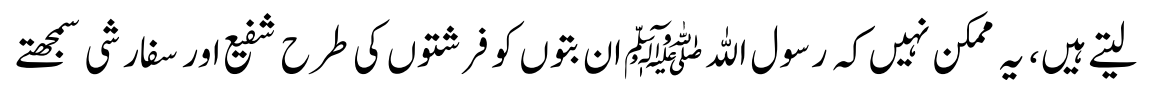

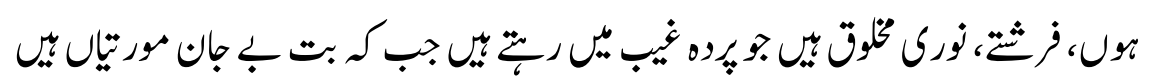

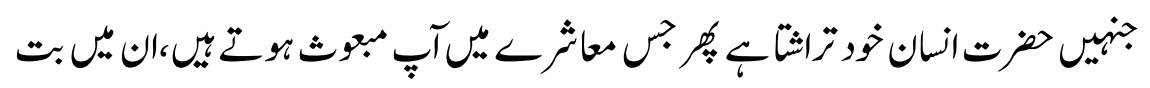

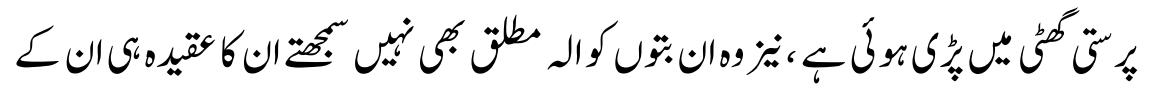

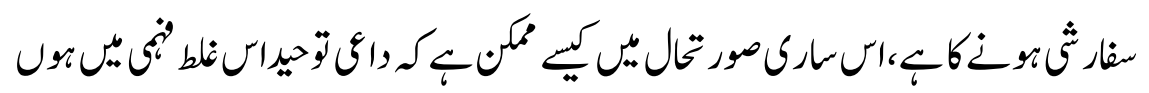

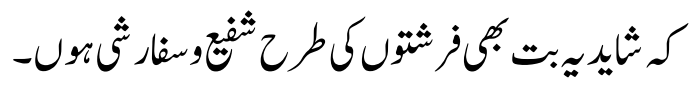

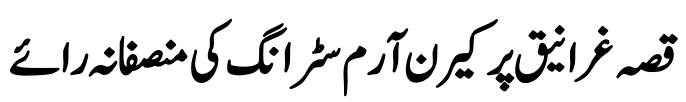




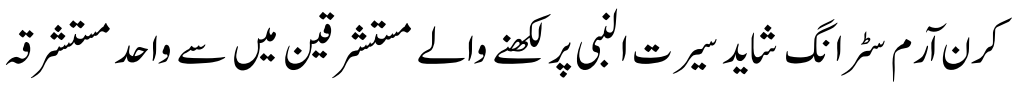

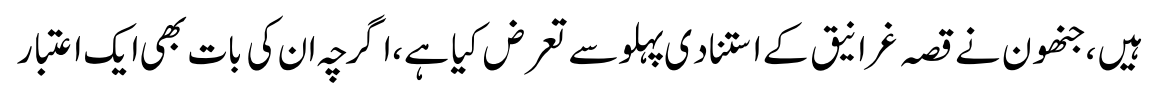

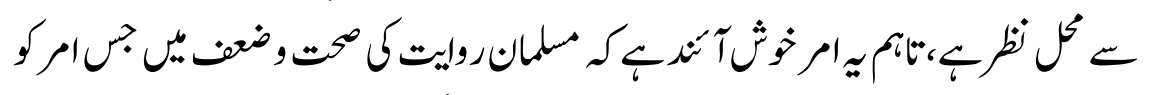

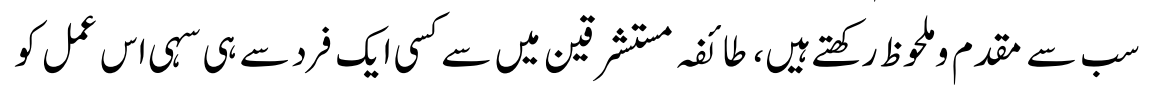

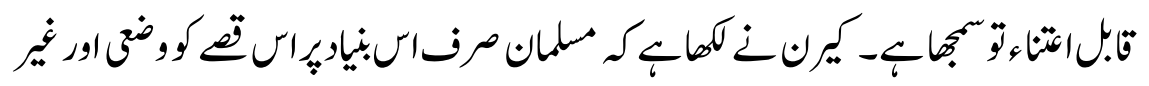

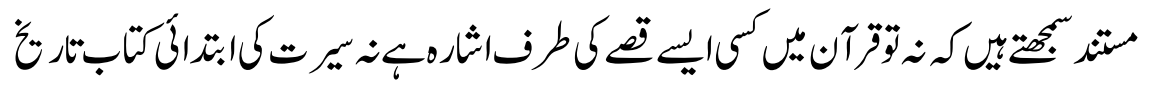

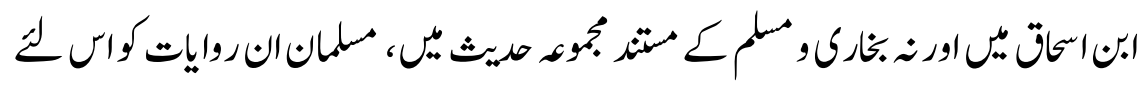

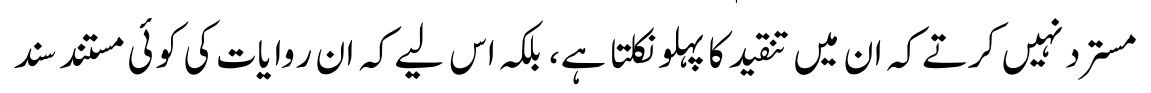

موبورن"

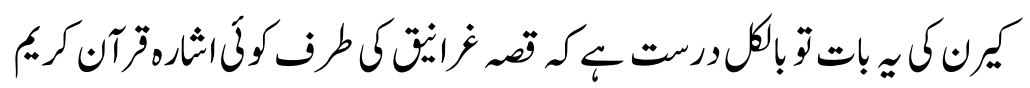

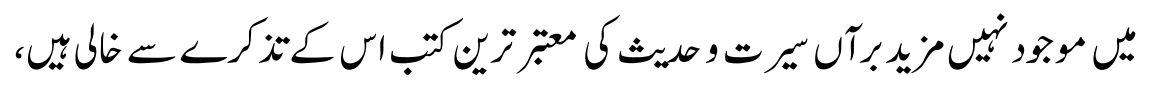

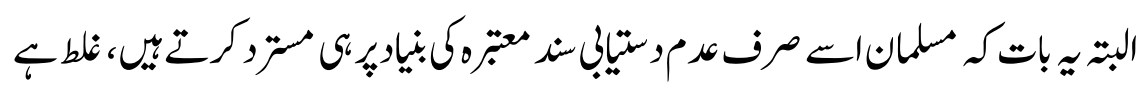

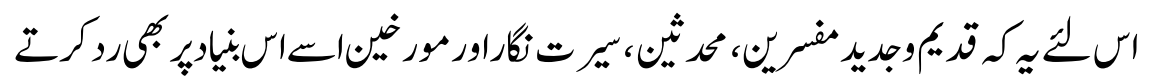

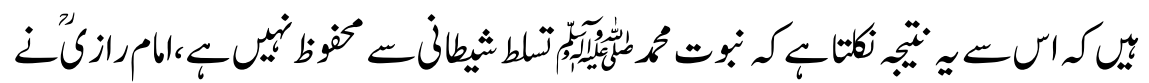

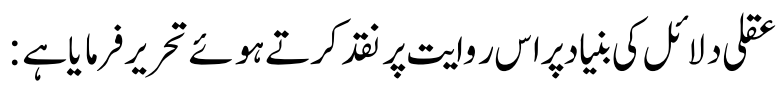

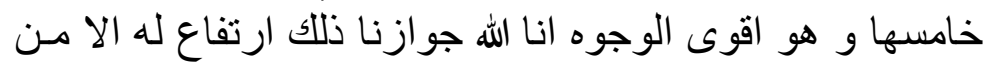

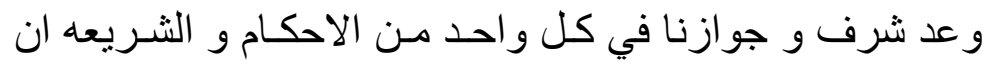

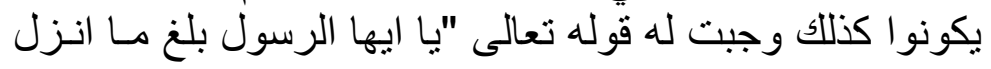

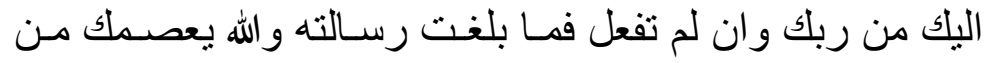

$$
\text { الناس" الخ } 42
$$

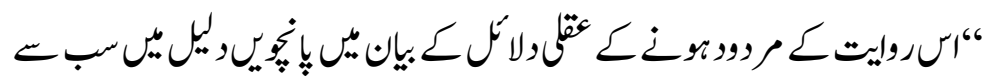

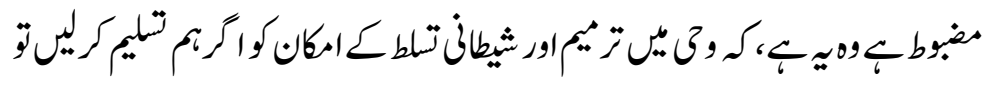

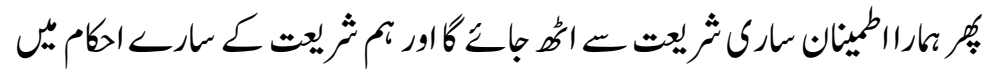




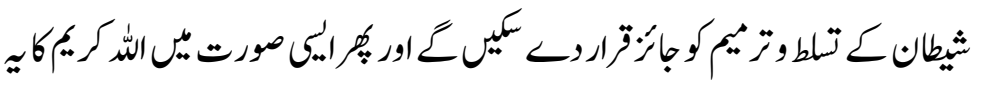

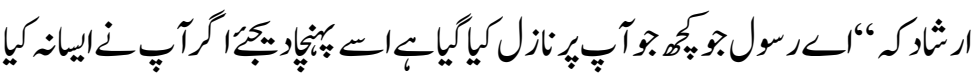

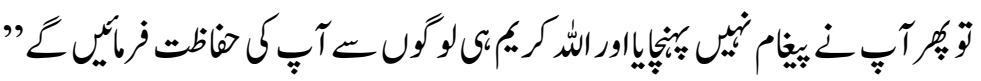

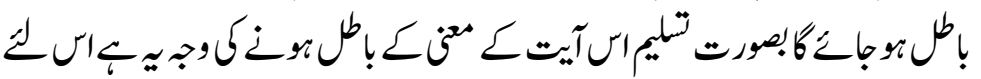

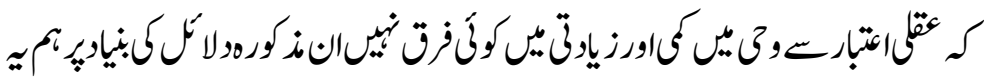

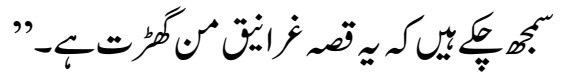

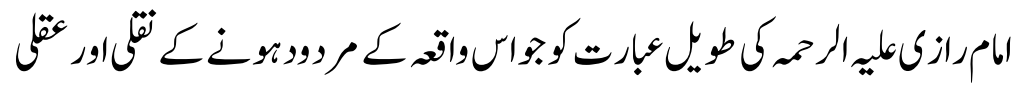

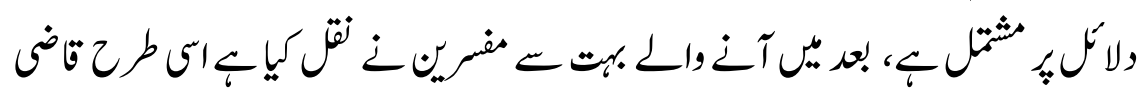
عياضر حمد لكمتين:

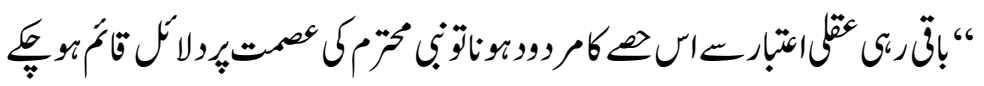

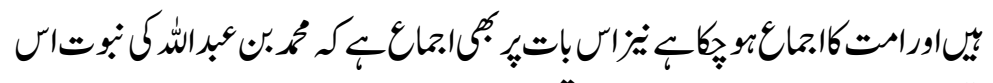

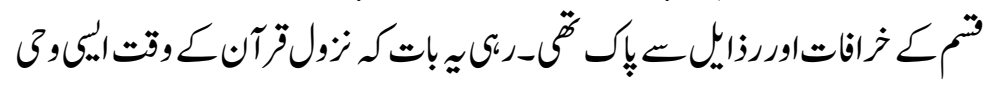

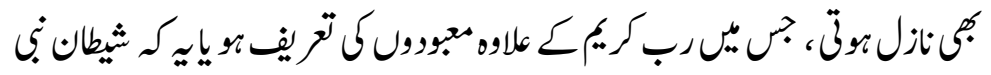

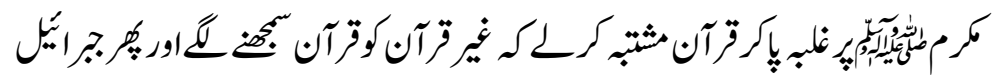

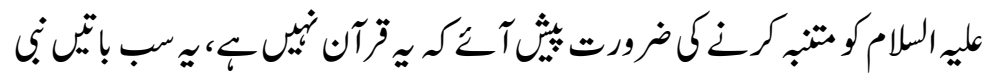

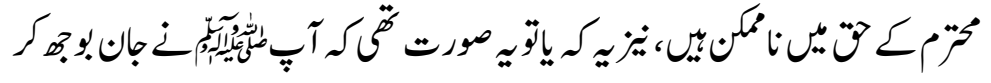

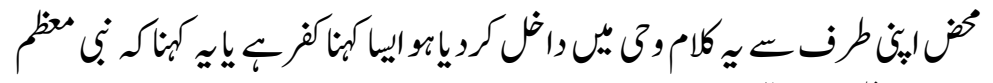

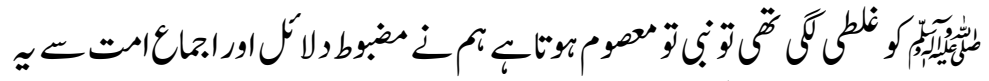

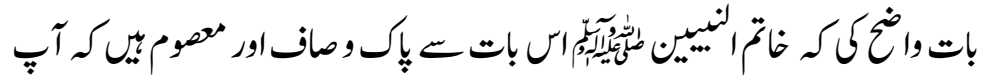

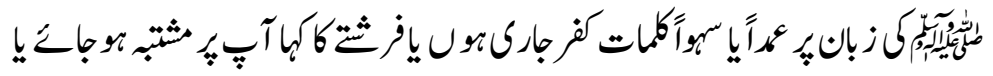

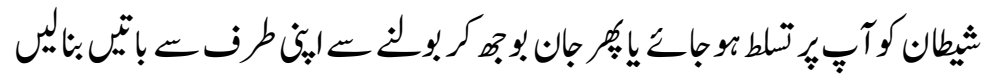

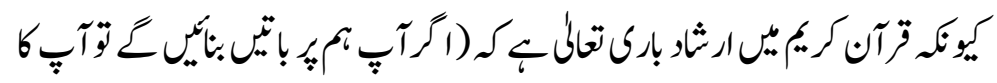




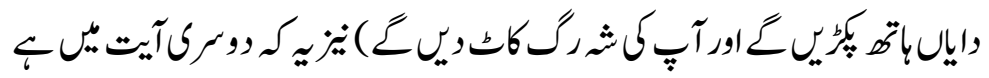

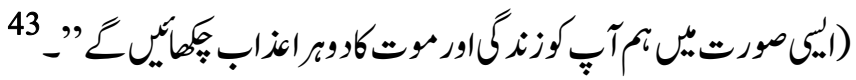

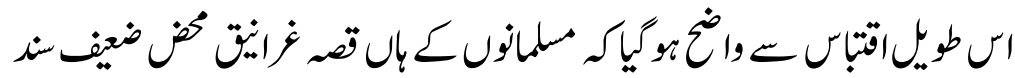

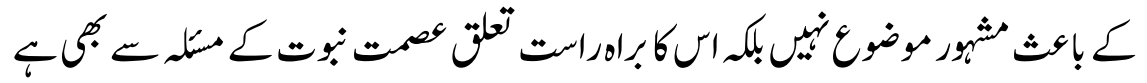

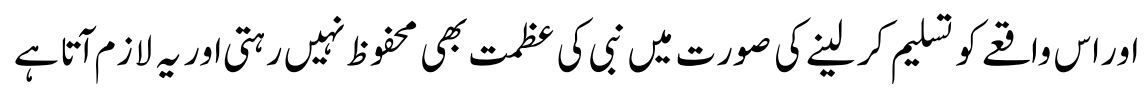

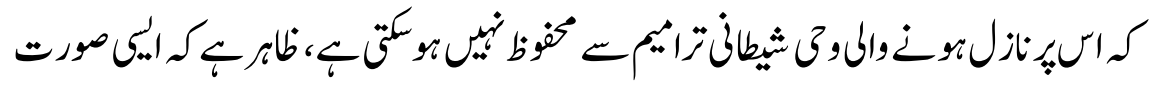

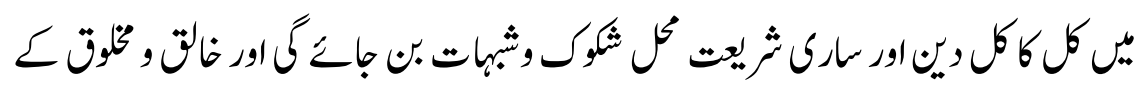

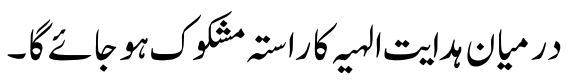

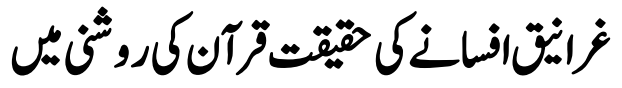

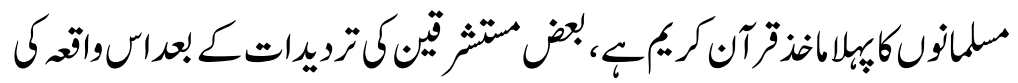

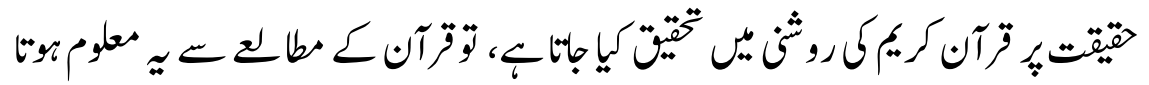

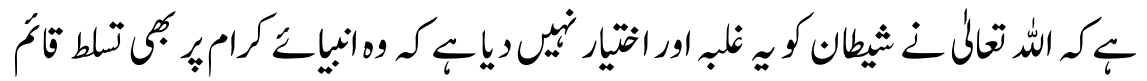

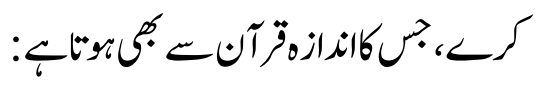

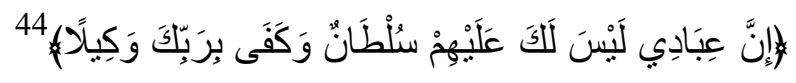

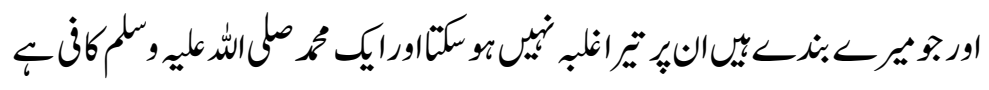

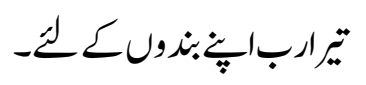

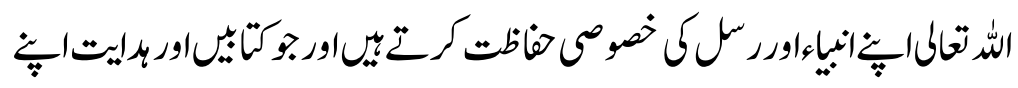

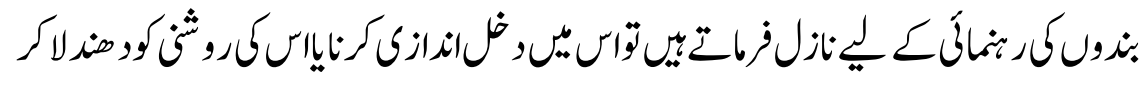

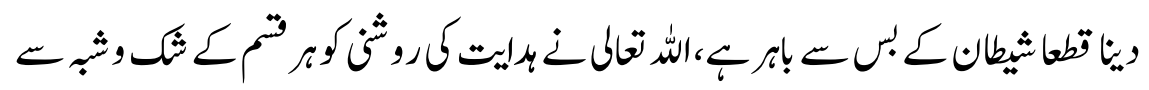

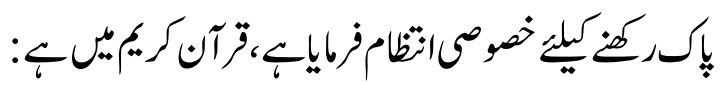




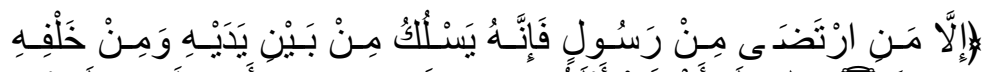

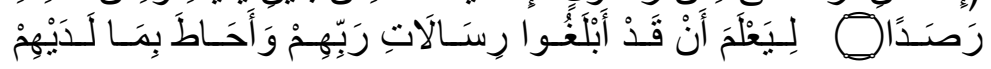

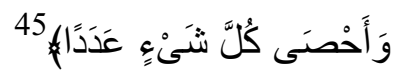

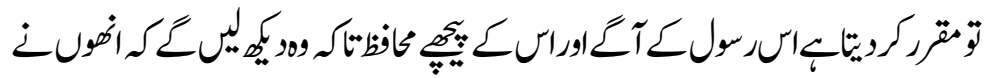

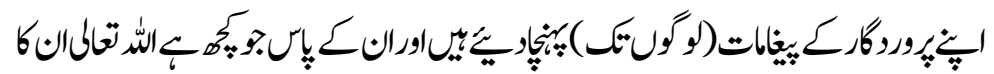

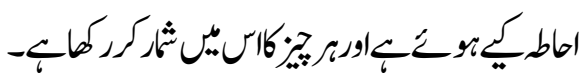

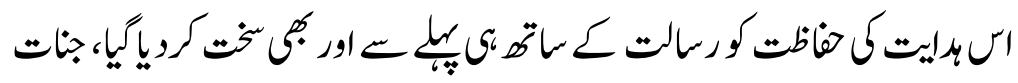

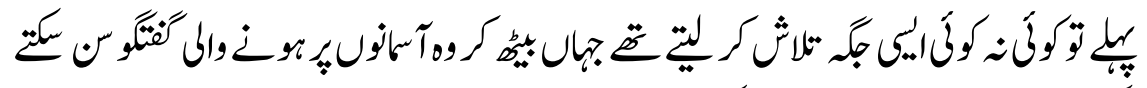

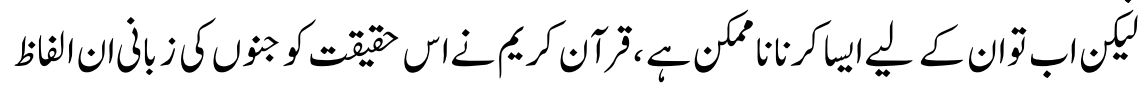

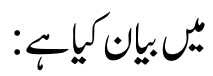

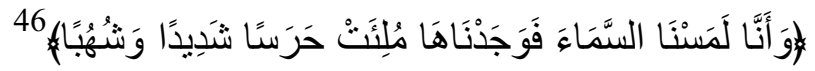

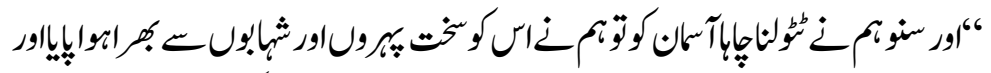

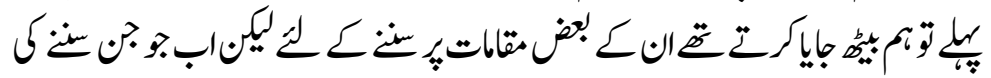

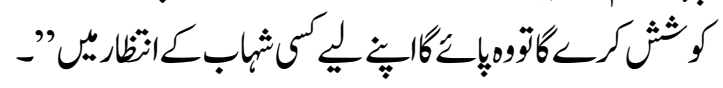

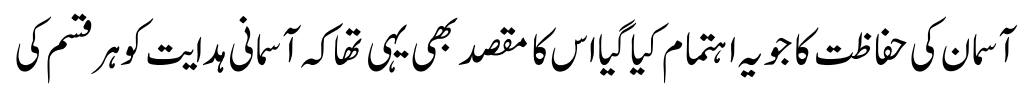

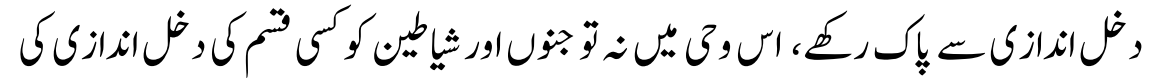

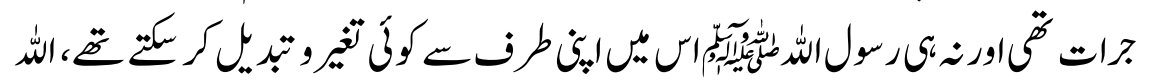
تعالكارشاتح

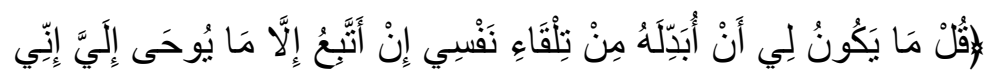

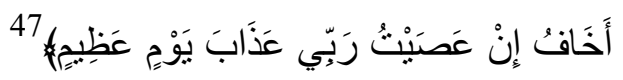

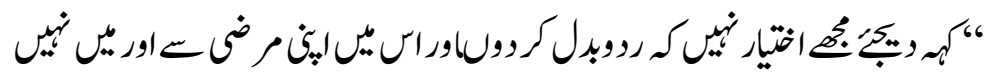

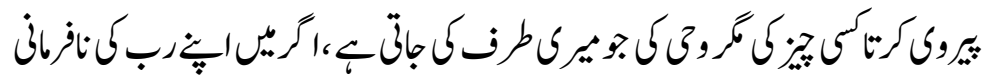

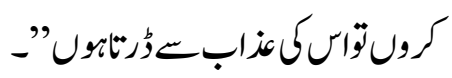




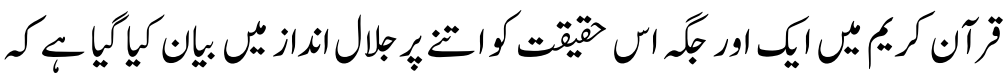

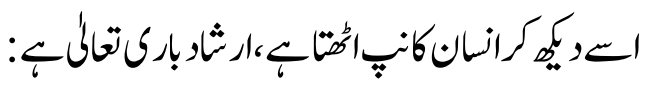

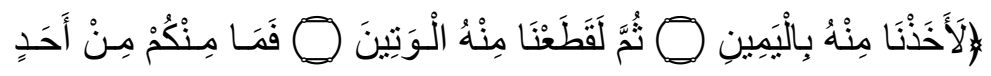

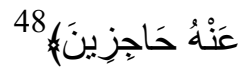

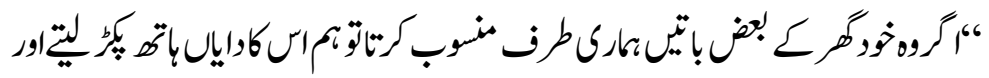

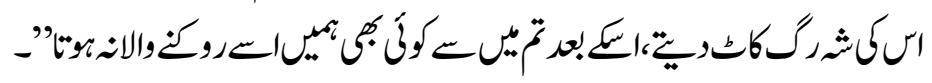

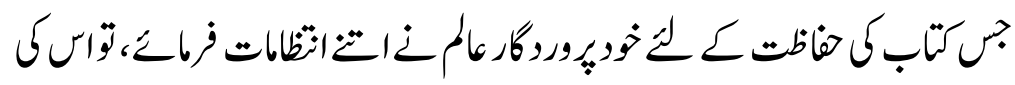

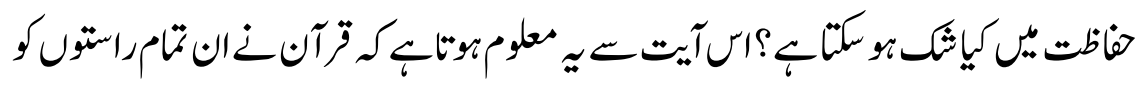

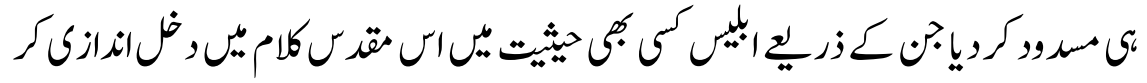

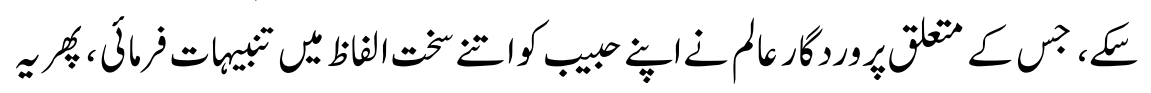

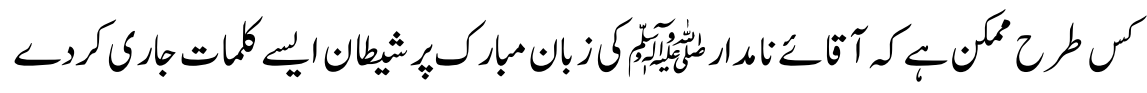

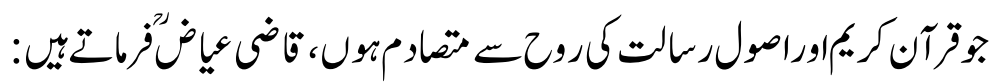

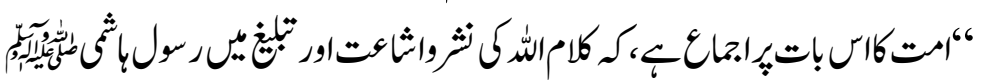

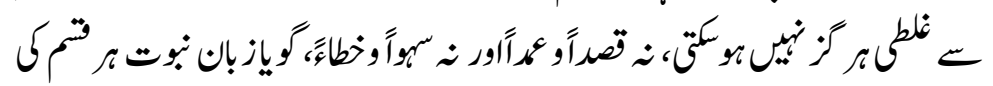

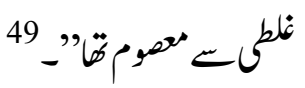

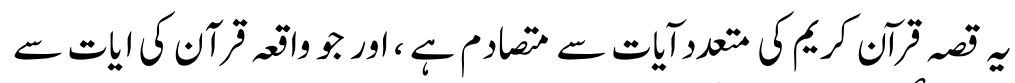

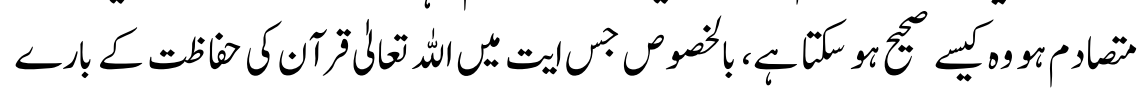
يّزماتيّ:

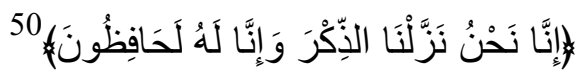

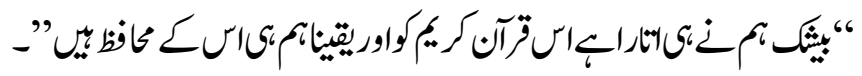

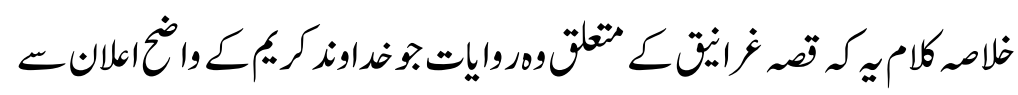

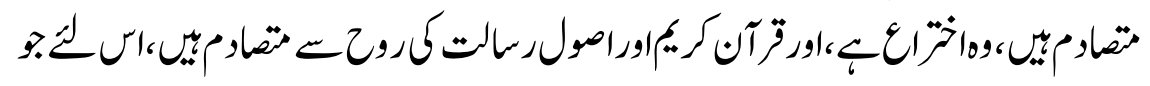




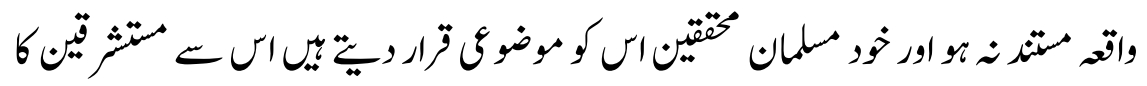

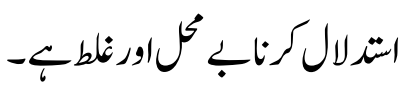

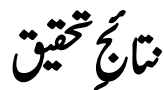

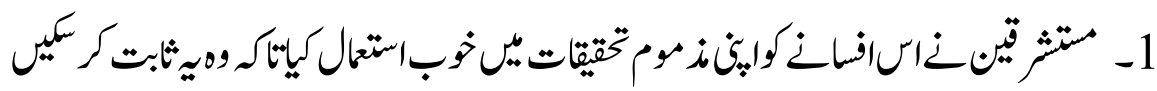

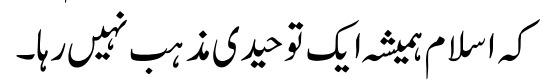

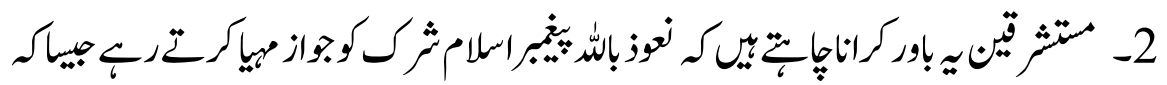

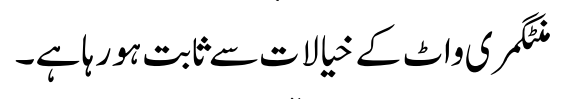

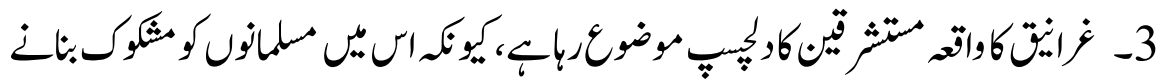

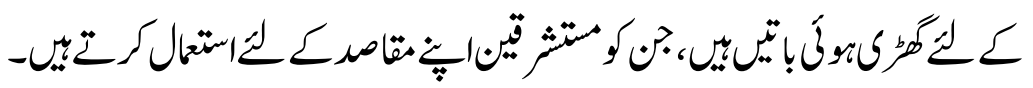

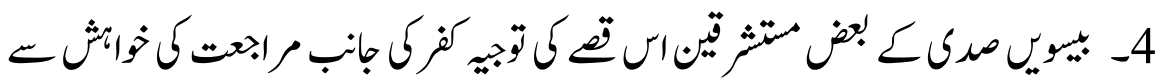

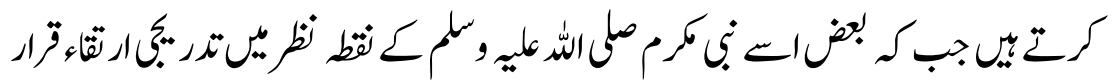

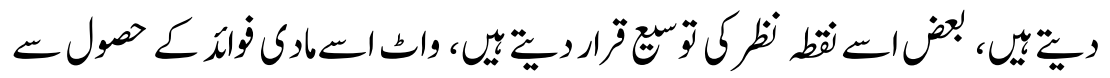

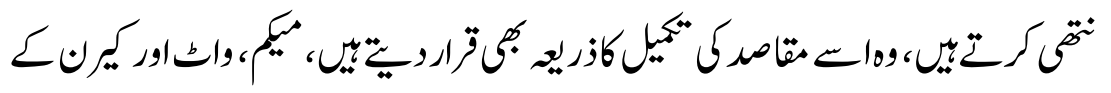

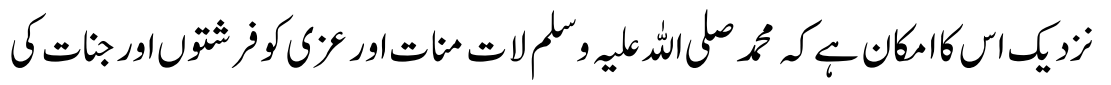

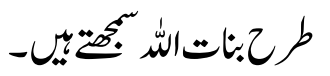

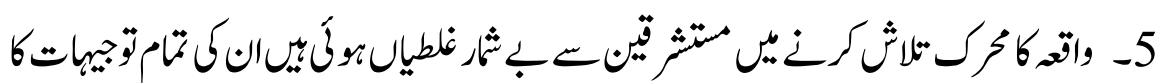

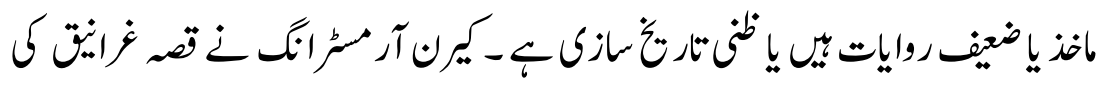

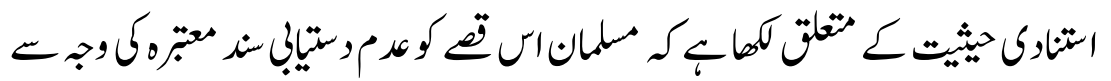

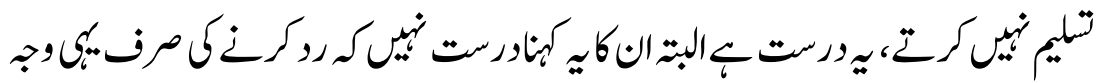

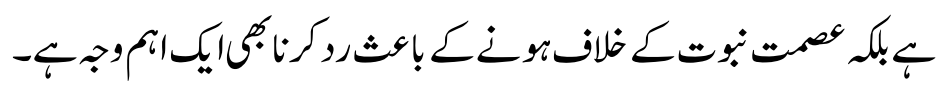

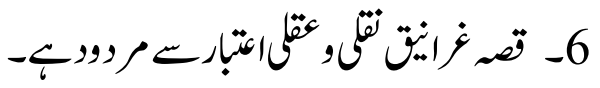




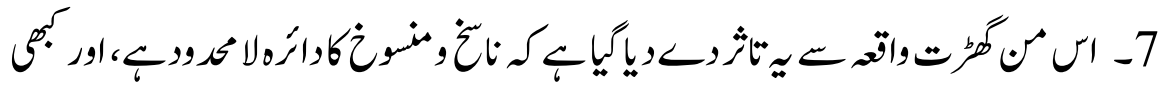

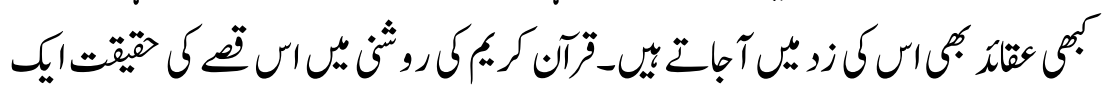
افساس

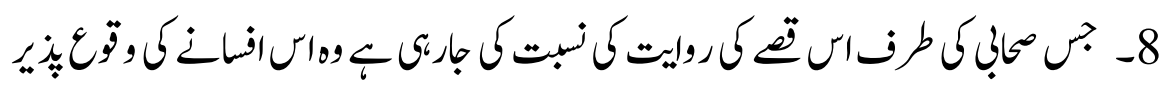

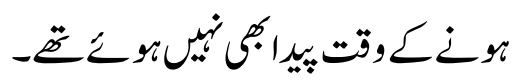
واثن وحوالم جات

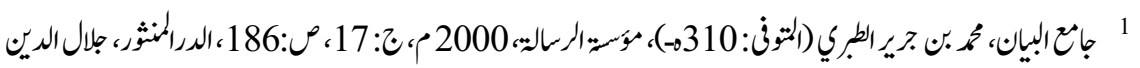

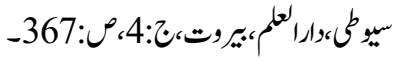

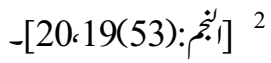

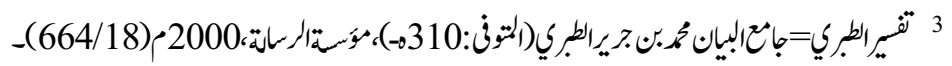

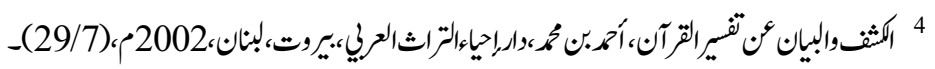

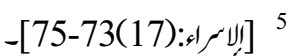
-[52(22):造 6

7 Muhammad: Prophet and Statesman, W. Montgomery Watt, Oxford University Press, p: 62 .

8 Muhammad: Prophet and Statesman, W. Montgomery Watt, Oxford University Press, p:61.

9 Muhammad: Prophet and Statesman, W. Montgomery Watt, Oxford University Press, p:60.

${ }^{10}$ Shorter Encyclopedia of Islam, H.A.R Gibbs, Brill, 1953, P:391.

$$
\begin{aligned}
& \text { [32(25): } \\
& \text { [35(46): ألاحقاف: }
\end{aligned}
$$

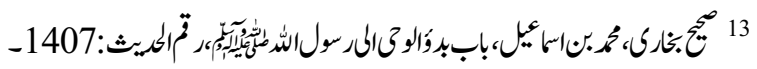

${ }^{14}$ Classical Islam, E.Von Grunebaum, Translated by Katherine Watson, London, 1970, P:31.

$$
\text { -[25(31):تمّان } 15
$$

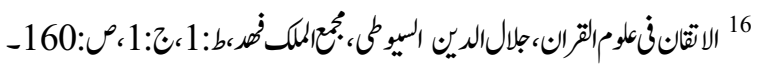


${ }^{18}$ Karen Armstrong, MUHAMMAD, A Western Attemp to Understand, Islam, London, 1991, P: 110.

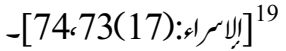

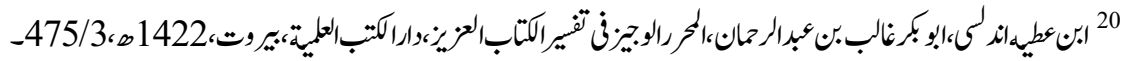

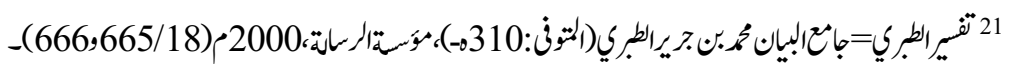

${ }^{22}$ Muhammad at Mecca, Watt, Montgomery, Oxford, 1953, PP: 108-109.

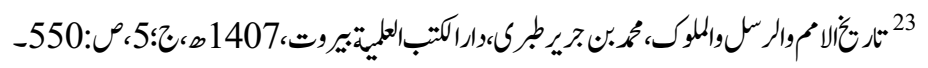

${ }^{24}$ Muhammad at Macca, PP: 103-104.

${ }^{25}$ Karen, Muhammad, P: 117.

${ }^{26}$ IBID, P: 113.

${ }^{27}$ IBID, P: 113.

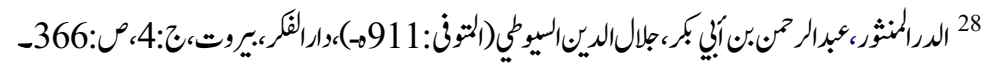

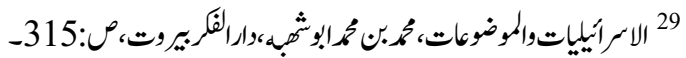

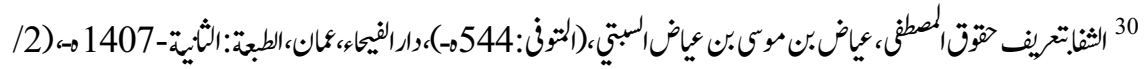

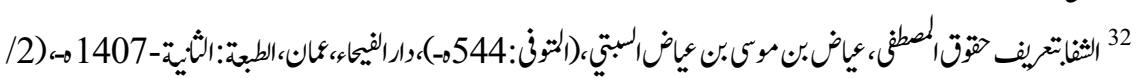

${ }^{33}$ Slman Rushdi, The Satanic Verses (London, Vintage Books 1988) .

${ }^{34} 114$ IBID, P:

${ }^{35}$ Muhammad at Mecca, Watt, Montgomery, Oxford, 1953, PP: 108.

$$
\begin{aligned}
& \text { 36 [الصافات:158(37)] } \\
& \text { [23(53):[م: }
\end{aligned}
$$

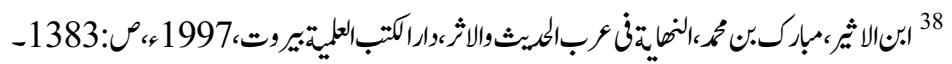

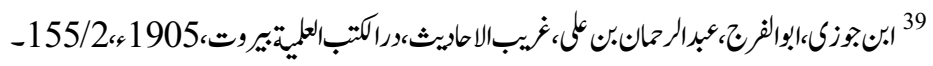

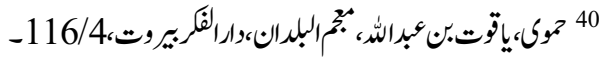


${ }^{41}$ Karen, Muhammad, P: 111.

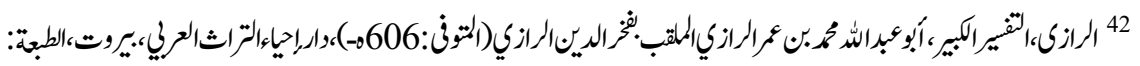

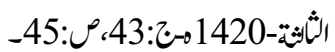

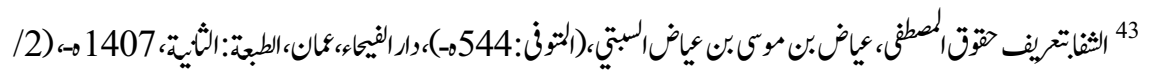

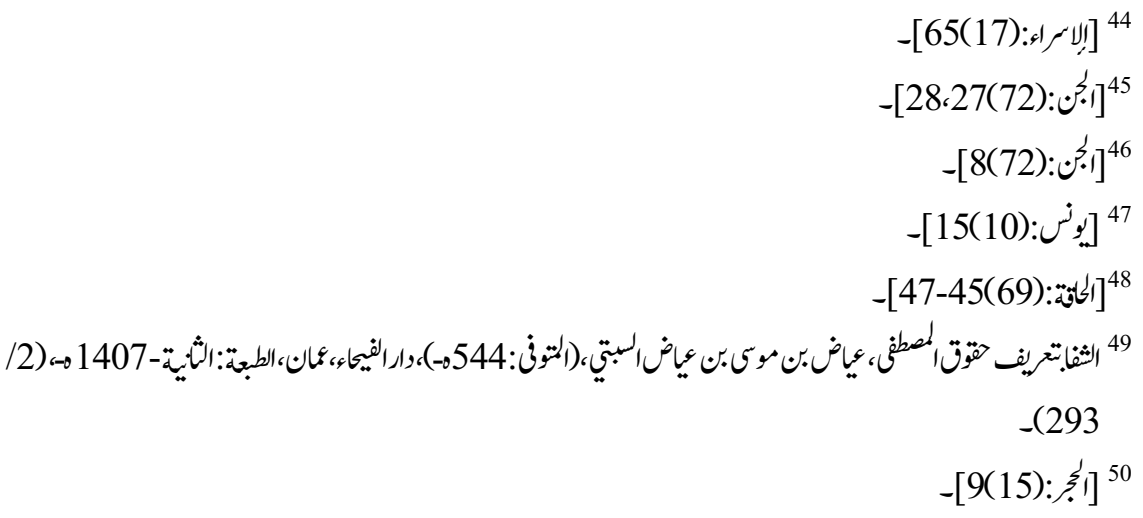

